\title{
Biogenic halocarbons from the Peruvian upwelling region as tropospheric halogen source
}

\author{
Helmke Hepach ${ }^{1, a}$, Birgit Quack ${ }^{1}$, Susann Tegtmeier ${ }^{1}$, Anja Engel ${ }^{1}$, Astrid Bracher ${ }^{2,3}$, Steffen Fuhlbrügge ${ }^{1}$, \\ Luisa Galgani $^{1, \mathrm{~b}}$, Elliot L. Atlas ${ }^{4}$, Johannes Lampel ${ }^{5}$, Udo Frieß ${ }^{5}$, and Kirstin Krüger ${ }^{6}$ \\ ${ }^{1}$ GEOMAR Helmholtz Centre for Ocean Research, Kiel, Germany \\ ${ }^{2}$ Alfred Wegener Institute (AWI), Helmholtz Centre for Polar and Marine Research, Bremerhaven, Germany \\ ${ }^{3}$ Institute of Environmental Physics, University of Bremen, Bremen, Germany \\ ${ }^{4}$ Rosenstiel School of Marine and Atmospheric Science (RSMAS), University of Miami, Miami, USA \\ ${ }^{5}$ Institute of Environmental Physics, University of Heidelberg, Heidelberg, Germany \\ ${ }^{6}$ Department of Geosciences, University of Oslo, Oslo, Norway \\ anow at: Environment Department, University of York, York, UK \\ ${ }^{b}$ now at: Department of Biotechnology, Chemistry and Pharmacy, University of Siena, Siena, Italy
}

Correspondence to: Helmke Hepach (hhepach@geomar.de)

Received: 15 January 2016 - Published in Atmos. Chem. Phys. Discuss.: 14 March 2016

Revised: 16 August 2016 - Accepted: 1 September 2016 - Published: 29 September 2016

\begin{abstract}
Halocarbons are produced naturally in the oceans by biological and chemical processes. They are emitted from surface seawater into the atmosphere, where they take part in numerous chemical processes such as ozone destruction and the oxidation of mercury and dimethyl sulfide. Here we present oceanic and atmospheric halocarbon data for the Peruvian upwelling zone obtained during the M91 cruise onboard the research vessel METEOR in December 2012. Surface waters during the cruise were characterized by moderate concentrations of bromoform $\left(\mathrm{CHBr}_{3}\right)$ and dibromomethane $\left(\mathrm{CH}_{2} \mathrm{Br}_{2}\right)$ correlating with diatom biomass derived from marker pigment concentrations, which suggests this phytoplankton group is a likely source. Concentrations measured for the iodinated compounds methyl iodide $\left(\mathrm{CH}_{3} \mathrm{I}\right)$ of up to $35.4 \mathrm{pmol} \mathrm{L}-1$, chloroiodomethane $\left(\mathrm{CH}_{2} \mathrm{ClI}\right)$ of up to $58.1 \mathrm{pmol} \mathrm{L}^{-1}$ and diiodomethane $\left(\mathrm{CH}_{2} \mathrm{I}_{2}\right)$ of up to $32.4 \mathrm{pmol} \mathrm{L}^{-1}$ in water samples were much higher than previously reported for the tropical Atlantic upwelling systems. Iodocarbons also correlated with the diatom biomass and even more significantly with dissolved organic matter (DOM) components measured in the surface water. Our results suggest a biological source of these compounds as a significant driving factor for the observed large iodocarbon concentrations. Elevated atmospheric mixing ratios of $\mathrm{CH}_{3} \mathrm{I}$ (up to $3.2 \mathrm{ppt}$ ), $\mathrm{CH}_{2} \mathrm{ClI}$ (up to $2.5 \mathrm{ppt}$ ) and $\mathrm{CH}_{2} \mathrm{I}_{2}$ (3.3 ppt)
\end{abstract}

above the upwelling were correlated with seawater concentrations and high sea-to-air fluxes. During the first part of the cruise, the enhanced iodocarbon production in the Peruvian upwelling contributed significantly to tropospheric iodine levels, while this contribution was considerably smaller during the second part.

\section{Introduction}

Brominated and iodinated short-lived halocarbons from the oceans contribute to tropospheric and stratospheric chemistry (von Glasow et al., 2004; Saiz-Lopez et al., 2012b; Carpenter and Reimann, 2014). They are significant carriers of iodine and bromine into the marine atmospheric boundary layer (Salawitch, 2006; Jones et al., 2010; Yokouchi et al., 2011; Saiz-Lopez et al., 2012b), where they and their degradation products may also be involved in aerosol and ultra-fine particle formation (O’Dowd et al., 2002; Burkholder et al., 2004). Furthermore, they play an important role for ozone chemistry and other processes such as the oxidation of several atmospheric constituents in the troposphere (Saiz-Lopez et al., 2012a). Numerous modelling studies over the last years have shown that brominated short-lived compounds and their degradation products can be entrained into the stratosphere 
and enhance the halogen-driven ozone destruction (Carpenter and Reimann, 2014; Hossaini et al., 2015). Recently, it was suggested that oceanic iodine in organic or inorganic form can also contribute to the stratospheric halogen loading, however only in small amounts due to its strong degradation (Tegtmeier et al., 2013; Saiz-Lopez et al., 2015).

While different source and sink processes determine the distribution of halocarbons in the oceanic surface water, the underlying mechanisms are largely unresolved. Biological activity plays a role for the production of bromoform $\left(\mathrm{CHBr}_{3}\right)$, dibromomethane $\left(\mathrm{CH}_{2} \mathrm{Br}_{2}\right)$, methyl iodide $\left(\mathrm{CH}_{3} \mathrm{I}\right)$, chloroiodomethane $\left(\mathrm{CH}_{2} \mathrm{ClI}\right)$ and diiodomethane $\left(\mathrm{CH}_{2} \mathrm{I}_{2}\right)$ (Gschwend et al., 1985; Tokarczyk and Moore, 1994; Moore et al., 1996), while $\mathrm{CH}_{3} \mathrm{I}$ also originates from photochemical reactions with dissolved organic matter (DOM) (Moore and Zafiriou, 1994; Bell et al., 2002; Shi et al., 2014).

Biologically mediated halogenation of DOM (Lin and Manley, 2012; Liu et al., 2015) and bromination of compounds such as $\beta$-diketones via enzymes like bromoperoxidase (BPO) within or outside the algal cells (Theiler et al., 1978) are among the potentially important production processes of $\mathrm{CHBr}_{3}$ and $\mathrm{CH}_{2} \mathrm{Br}_{2}$. Air-sea gas exchange into the atmosphere is the most important sink for both compounds in the surface ocean (Quack and Wallace, 2003; Hepach et al., 2015).

The biological formation of $\mathrm{CH}_{3} \mathrm{I}$ has been investigated during laboratory and field studies (Scarratt and Moore, 1998; Amachi et al., 2001; Fuse et al., 2003; Smythe-Wright et al., 2006; Brownell et al., 2010; Hughes et al., 2011) identifying phyto- and bacterioplankton as producers, revealing large variability in biological production rates. However, biogeochemical modelling studies suggest that photochemistry may be more important for global $\mathrm{CH}_{3} \mathrm{I}$ production (Stemmler et al., 2014). Due to their much shorter lifetime in surface water and the atmosphere, fewer studies have investigated production processes of $\mathrm{CH}_{2} \mathrm{I}_{2}$ and $\mathrm{CH}_{2} \mathrm{ClI}$. $\mathrm{CH}_{2} \mathrm{I}_{2}$ has been suggested to be produced by both phytoplankton (Moore et al., 1996) and bacteria (Fuse et al., 2003; Amachi, 2008). The main source for $\mathrm{CH}_{2} \mathrm{ClI}$ is likely its production during the photolysis of $\mathrm{CH}_{2} \mathrm{I}_{2}$ with a yield of $35 \%$ based on a laboratory study (Jones and Carpenter, 2005). $\mathrm{CH}_{2} \mathrm{ClI}$ has also been detected in phytoplankton cultures (Tokarczyk and Moore, 1994), where it may originate from direct production or also from $\mathrm{CH}_{2} \mathrm{I}_{2}$ conversion. The main sink for both $\mathrm{CH}_{2} \mathrm{I}_{2}$ and $\mathrm{CH}_{2} \mathrm{ClI}$ is photolytical breakdown in the surface ocean resulting in lifetimes of less than $10 \mathrm{~min}\left(\mathrm{CH}_{2} \mathrm{I}_{2}\right)$ and $9 \mathrm{~h}\left(\mathrm{CH}_{2} \mathrm{ClI}\right)$, respectively, in the tropical ocean (Jones and Carpenter, 2005; Martino et al., 2006). Other sinks for these three iodocarbons are air-sea gas exchange and chloride substitution. The latter may play an important role for $\mathrm{CH}_{3} \mathrm{I}$ in low latitudes at low wind speeds (Zafiriou, 1975; Jones and Carpenter, 2007).

Oceanic measurements of natural halocarbons are sparse (Ziska et al., 2013), but they reveal that especially tropical and subtropical upwelling systems are potentially important source regions (Quack et al., 2007a; Raimund et al., 2011). Previously observed high tropospheric iodine monoxide (IO) levels in the tropical eastern Pacific have been related to short-lived iodinated compounds in surface waters (Schönhardt et al., 2008; Dix et al., 2013). However, iodocarbon fluxes have not been considered high enough to explain observed IO concentrations (Jones et al., 2010; Mahajan et al., 2010; Großmann et al., 2013; Lawler et al., 2014), and recent global modelling studies have suggested abiotic sources contributing on average about $75 \%$ to the IO budget (PradosRoman et al., 2015). Such abiotic sources could be emissions of hypoiodous acid (HOI) and molecular iodine $\left(\mathrm{I}_{2}\right)$ as recently confirmed by a laboratory study (Carpenter et al., 2013).

This paper characterizes the Peruvian upwelling region between $5.0^{\circ} \mathrm{S}, 82.0^{\circ} \mathrm{W}$ and $16.2^{\circ} \mathrm{S}, 76.8^{\circ} \mathrm{W}$ with regard to the two brominated compounds $\mathrm{CHBr}_{3}$ and $\mathrm{CH}_{2} \mathrm{Br}_{2}$ and the iodinated compounds $\mathrm{CH}_{3} \mathrm{I}, \mathrm{CH}_{2} \mathrm{ClI}$ and $\mathrm{CH}_{2} \mathrm{I}_{2}$ in water and atmosphere. $\mathrm{CH}_{2} \mathrm{ClI}$ and $\mathrm{CH}_{2} \mathrm{I}_{2}$ were measured for the first time in this region. Possible oceanic sources based on the analysis of phytoplankton species composition and different DOM components were evaluated and identified. Sea-to-air fluxes of these halogenated compounds were derived and their contribution to the tropospheric iodine loading above the tropical eastern Pacific were estimated by combining halocarbon, IO measurements and model calculations.

\section{Methods}

The M91 cruise of the R/V METEOR from 1 to 26 December 2012 investigated the surface ocean and atmosphere of the Peruvian upwelling region (Bange, 2013). From the northernmost location of the cruise at $5.0^{\circ} \mathrm{S}$ and $82.0^{\circ} \mathrm{W}$, the ship moved to the southernmost position at $16.2^{\circ} \mathrm{S}$ and $76.8^{\circ} \mathrm{W}$ with several transects perpendicular to the coast, alternating between open-ocean and coastal upwelling (Fig. 1). All underway measurements were taken from a continuously operating pump in the ship's hydrographic shaft from a depth of $6.8 \mathrm{~m}$. Sea surface temperature (SST) and sea surface salinity (SSS) were measured continuously with a SeaCAT thermosalinograph from Sea-Bird Electronics (SBE).

Deep samples were taken from 4 to 10 depths between 1 and $2000 \mathrm{~m}$ from $12 \mathrm{~L}$ Niskin bottles attached to a 24-bottle rosette sampler equipped with a CTD and an oxygen sensor from SBE. Halocarbon samples were collected at 24 of the total 98 casts. The uppermost sample from the depth profiles (between 1 and $10 \mathrm{~m}$ ) was included in the surface water measurements.

\subsection{Analysis of halocarbon samples}

Halocarbon samples were taken every $3 \mathrm{~h}$ throughout the whole day from sea surface water and air. Water was sampled bubble-free in $300 \mathrm{~mL}$ amber glass bottles. Surface wa- 

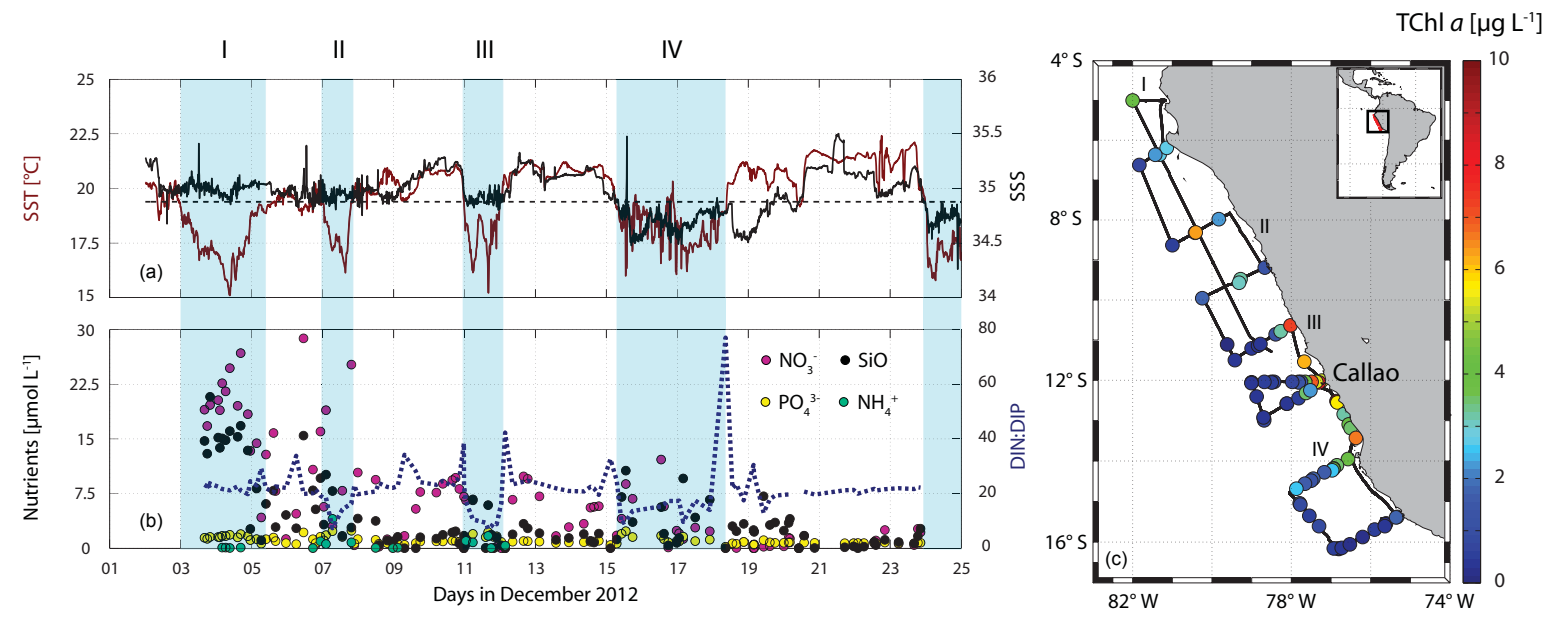

Figure 1. Ambient parameters during the M91 cruise: SST (dark red) and sea surface salinity (SSS) (black) in panel (a) with the dashed line as the mean SST. Nutrients (purple is nitrate $-\mathrm{NO}_{3}^{-}$; yellow is phosphate $-\mathrm{PO}_{4}^{3-}$; black is silicate $-\mathrm{SiO}_{2}$; light cyan is ammonium - $\mathrm{NH}_{4}^{+}$) with the $\mathrm{N}$ to $\mathrm{P}$ ratio (dark-blue dashed line) are shown in panel (b). Total chlorophyll $a$ (TChl $a$ ) is shown in the map in panel (c). The light-blue shaded areas stand for the regions where SST is below the mean, indicating upwelling of cold water. All M91 data can be accessed at PANGAEA (Hepach et al., 2016).

ter samples were analysed on board with a purge and trap system attached to a GC-MS (combined gas chromatograph and mass spectrometer), which is described in more detail in Hepach et al. (2014). The depth profile samples were analysed with a similar setup: a purge and trap system was attached to a GC equipped with an ECD (electron capture detector). The precision of the measurements was within $10 \%$ for all five halocarbons determined from duplicates and both systems were calibrated using the same liquid standards in methanol. The purge efficiency for all compounds in both setups was larger than $98 \%$ with a sample volume of $50 \mathrm{~mL}$, a purging temperature of $70^{\circ} \mathrm{C}$, and a purge stream of $30 \mathrm{~mL} \mathrm{~min}^{-1}$. Halocarbon measurements in seawater started only on 9 December due to instrument issues. Atmospheric halocarbon samples were taken in pre-cleaned stainless steel canisters on the monkey deck at a height of $20 \mathrm{~m}$ above sea level using a metal bellows pump starting on 1 December, and were analysed at the Rosenstiel School of Marine and Atmospheric Science (RSMAS) as described in Schauffler et al. (1998). For further details of atmospheric measurements, see Fuhlbrügge et al. (2016a). Quantification was achieved using the NOAA standard SX3573 from GEOMAR.

\subsection{Biological parameters}

Phytoplankton composition was derived from pigment concentrations. Samples were taken in parallel with the halocarbon samples in the sea surface and up to six samples in depths between 3 and $200 \mathrm{~m}$. Water was filtered through $\mathrm{GF} / \mathrm{F}$ filters, which were stored at $-80^{\circ} \mathrm{C}$ until analysis after shock-freezing in liquid nitrogen. Pigments as described in Taylor et al. (2011) were analysed using a HPLC technique according to Barlow et al. (1997). We used the diagnostic pigment analysis by Vidussi et al. (2001), subsequently refined by Uitz et al. (2006) by introducing pigment specific weight coefficients, to determine the chlorophyll $a$ (Chl $a$ ) concentration of seven groups of phytoplankton which are assumed to comprise the entire phytoplankton community in ocean waters. Identified phytoplankton groups include diatoms, chlorophytes, dinoflagellates, haptophytes, cyanobacteria, cryptophytes and chrysophytes. Total chlorophyll $a$ (TChl $a$ ) concentrations were calculated from the sum of the pigment concentrations of monovinyl $\mathrm{Chl} a$, divinyl $\mathrm{Chl} a$ and chlorophyllide $a$.

Samples for the identification of DOM components were taken at 37 stations from a rubber boat from subsurface water at approximately $20 \mathrm{~cm}$. Very well mixed layers at these measurement locations reach down to between 6 and $25 \mathrm{~m}$, and DOM turnover times for the respective compounds has been reported to be several days to months (Engel et al., 2011; Hansell, 2013). All samples were processed onboard and analysed back in the home laboratory. Samples were analysed for dissolved and total organic carbon (DOC and TOC), total dissolved nitrogen (TDN) and total nitrogen (TN) by a high-temperature catalytic oxidation method using a TOC analyser (TOC- $\mathrm{V}_{\mathrm{CSH}}$ ) from Shimadzu. Total, dissolved and particulate high-molecular-weight (HMW, $>1 \mathrm{kDa}$ ) combined carbohydrates (TCCHO, DCCHO and PCCHO), as well as total, dissolved and particulate combined HMW uronic acids (TURA, DURA and PURA), i.e. galacturonic acid and glucuronic acid, were analysed by means of high-performance anion exchange chromatography coupled with pulsed amperometric detection (HPAEC-PAD) after Engel and Händel (2011). For a more detailed descrip- 
tion of both the sampling method and analysis, see Engel and Galgani (2016a), and for data see Hepach et al. (2016).

\subsection{Correlation analysis}

Correlation analyses between all halocarbons, biological proxies and ambient parameters were carried out using Matlab ${ }^{\circledR}$ for all collocated surface and depth samples. All datasets were tested for normal distribution using the Lilliefors test. Since most of the data were not distributed normally, Spearman's rank correlation (hereinafter $r_{\mathrm{s}}$ ) was used. All correlations with a significance level of smaller than $5 \%$ $(p<0.05)$ were regarded as significant.

\subsection{Calculation of sea-to-air fluxes}

Sea-to-air fluxes, $F$, of halocarbons were calculated according to Eq. (1):

$F=k_{\mathrm{w}} \times\left(c_{\mathrm{w}}-\frac{c_{\mathrm{atm}}}{H}\right)$,

where $k_{\mathrm{W}}$ is the gas exchange coefficient parameterized according to Nightingale et al. (2000), $c_{\mathrm{W}}$ and $c_{\mathrm{atm}}$ are the water concentrations from the halocarbon underway measurements and from the simultaneous atmospheric measurements, respectively, and $H$ is the Henry's law constant to derive the equilibrium concentration. The gas exchange coefficient usually applied to derive carbon dioxide fluxes was adjusted for halocarbons using Schmidt number corrections as calculated in Quack and Wallace (2003), and Henry's law coefficients as reported for each of the compounds by Moore et al. (1995) were applied. Wind speed and air pressure were averaged to $10 \mathrm{~min}$ intervals for the calculation of the instantaneous fluxes.

\subsection{MAX-DOAS measurements of IO}

Multi-axis differential optical absorption spectroscopy (MAX-DOAS) (Hönninger, 2002; Platt and Stutz, 2008) observations were conducted continuously in the daytime from 30 November to 25 December 2012 in order to quantify tropospheric abundances of $\mathrm{IO}, \mathrm{BrO}, \mathrm{HCHO}$, glyoxal, $\mathrm{NO}_{2}$ and HONO along the cruise track, as well as aerosol profiles of $\mathrm{O}_{4}$. The MAX-DOAS instrument and the measurement procedure are described in Großmann et al. (2013) and Lampel et al. (2015).

The primary quantity derived from MAX-DOAS measurements is the differential slant column density (dSCD), which represents the difference in path-integrated concentrations between two measurements in the off-axis and zenith direction. From the MAX-DOAS observations of $\mathrm{O}_{4} \mathrm{dSCD}$ aerosol extinction profiles to estimate the quality of visibility were inferred using an optimal estimation approach described in Frieß et al. (2006) and Yilmaz (2012) after applying a correction factor of 1.25 to the $\mathrm{O}_{4} \mathrm{dSCDs}$ (Clémer et al., 2010). IO was analysed in the spectral range from 418 to $438 \mathrm{~nm}$ following the settings in Lampel et al. (2015). IO was found up to 6 times above the detection limit (twice the measurement error).

\subsection{FLEXPART simulations of tropospheric iodine}

The atmospheric transport of the iodocarbons from the oceanic surface into the marine atmospheric boundary layer (MABL) was simulated with the Lagrangian particle dispersion model FLEXPART (Stohl et al., 2005), which has been used extensively in studies of long-range and mesoscale transport (Stohl and Trickl, 1999). FLEXPART is an offline model driven by external meteorological fields. It includes parameterizations for moist convection, turbulence in the boundary layer, dry deposition, scavenging, and the simulation of chemical decay. We simulate trajectories of a multitude of air parcels describing transport and chemical decay of the emitted oceanic iodocarbons. For each data point of the observed sea-to-air flux, 100000 air parcels were released over the duration of the M91 cruise from a $0.1^{\circ} \times 0.1^{\circ}$ grid box at the ocean surface centred at the measurement location. We used FLEXPART version 9.2 and the runs are driven by the ECMWF reanalysis product ERA-Interim (Dee et al., 2011) given at a horizontal resolution of $1^{\circ} \times 1^{\circ}$ on 60 model levels. Transport, dispersion and convection of the air parcels are calculated from the 6-hourly fields of horizontal and vertical wind, temperature, specific humidity, convective and large-scale precipitation, and other parameters. The chemical decay of the iodocarbons was prescribed by their atmospheric lifetime which was set to 4 days, $9 \mathrm{~h}$ and 10 min for $\mathrm{CH}_{3} \mathrm{I}, \mathrm{CH}_{2} \mathrm{ClI}$, and $\mathrm{CH}_{2} \mathrm{I}_{2}$, respectively, according to current estimates (Jones and Carpenter, 2005; Martino et al., 2006; Carpenter and Reimann, 2014). After degradation of the iodocarbons, the released iodine was simulated as an inorganic iodine $\left(\mathrm{I}_{y}\right)$ tracer with a prescribed lifetime in the marine boundary layer of 2 days (Sherwen et al., 2016). Thus, we did not include detailed tropospheric iodine chemistry; explicit removal of $\mathrm{HOI}, \mathrm{HI}, \mathrm{IONO}_{2}$, and $\mathrm{I}_{x} \mathrm{O}_{y}$ through scavenging; or heterogeneous recycling of $\mathrm{HOI}, \mathrm{IONO}_{2}$, and $\mathrm{INO}_{2}$ on aerosols. In order to estimate the uncertainties arising from this simplification, we conducted two additional simulations, one with a very short lifetime of 1 day and one with a longer lifetime of 3 days. Following model simulations of halogen chemistry for air masses from different oceanic regions in Sommariva and von Glasow (2012), IO corresponds to $20 \%$ of the $\mathrm{I}_{y}$ budget in the marine boundary layer on a daytime average. The $\mathrm{IO}$ to $\mathrm{I}_{y}$ ratio shows moderate changes during daytime, resulting in the highest IO proportion at sunrise $(\sim 30 \%)$ and the lowest IO proportion around noon $(\sim 15 \%)$ (see Fig. S6 in Sommariva and von Glasow, 2012). The ratio shows only very small variations for different air mass origins and thus the chemical conditions such as ozone and nitrogen species concentrations. Additionally, the ratio does not change much with altitude within the marine boundary layer. Based on the above estimates from 
Sommariva and von Glasow (2012), we used the IO to $\mathrm{I}_{y}$ ratio as a function of daytime to estimate $\mathrm{IO}$ from $\mathrm{I}_{y}$ every $3 \mathrm{~h}$. Daily averages of the IO abundance were compared to the MAX-DOAS IO measurements on board described in the previous section.

\section{The tropical eastern Pacific - general description and state during M91}

The tropical eastern Pacific is characterized by one of the strongest and most productive all-year-prevailing eastern boundary upwelling systems of the world (Bakun and Weeks, 2008). Temperatures drop to less than $16^{\circ} \mathrm{C}$ when cold water from the Humboldt current is transported to the surface due to Ekman transport caused by strong equatorward winds (Tomczak and Godfrey, 2005), which is also connected to an upward transport of nutrients (Chavez et al., 2008). As a consequence of the enhanced nutrient supply and the high solar insolation, phytoplankton blooms, indicated by high Chl $a$ values, can be observed at the surface, especially in the boreal winter months (Echevin et al., 2008). A strong oxygen minimum zone (OMZ) is formed due to enhanced primary production, sinking particles and weak circulation (Karstensen et al., 2008).

Low SSTs of mean $(\min -\max ) 19.415 .0-22.4)^{\circ} \mathrm{C}$ and high TChl $a$ values of on average $1.80(0.06-12.65) \mu \mathrm{g} \mathrm{L}^{-1}$ (Table 1, Fig. 1) were measured during our cruise. Diatoms dominated the TChl $a$ concentration in the surface water with a mean of $1.66(0.00-10.47) \mu \mathrm{Chl} a \mathrm{~L}^{-1}$, followed by haptophytes (mean: $0.25 \mu \mathrm{g} \mathrm{Chl} a \mathrm{~L}^{-1}$ ), chlorophytes (mean: $0.19 \mu \mathrm{g} \mathrm{Chl} a \mathrm{~L}^{-1}$ ), cyanobacteria (mean: $0.09 \mu \mathrm{g} \mathrm{Chl} a \mathrm{~L}^{-1}$ ), dinoflagellates (mean: $0.08 \mu \mathrm{g} \mathrm{Chl} a \mathrm{~L}^{-1}$ ), cryptophytes (mean: $0.03 \mu \mathrm{g} \mathrm{Chl} a \mathrm{~L}^{-1}$ ), and finally chrysophytes (mean: $0.03 \mu \mathrm{g} \mathrm{Chl} a \mathrm{~L}^{-1}$ ). Diatoms were observed at all stations, with concentrations above $0.5 \mu \mathrm{g} \mathrm{Chl} a \mathrm{~L}^{-1}$ contributing more than $50 \%$ of the algal biomass. They were significantly correlated with TChl $a$ (Table 2) and with cryptophytes, which were elevated in very similar regions. Abundance of these phytoplankton groups was strongly anticorrelated with SST and SSS, indicating a close conjunction with the colder and more saline upwelling waters. Nutrients (nitrate, nitrite, ammonium and phosphate) were also measured during the cruise (see Czeschel et al., 2015, for further information). A weak anticorrelation of phytoplankton with the ratio of dissolved inorganic nitrogen and phosphate (sum of nitrate, nitrite and ammonium divided by phosphate, DIN : DIP) (Table 2) indicated that diatoms and cryptophytes were more abundant in aged upwelling, where nutrients were already slightly depleted or used up. The TChl $a$ maximum was generally found in the surface ocean except for four stations with overall low TChl $a\left(<0.5 \mu \mathrm{g} \mathrm{L}{ }^{-1}\right)$ where a subsurface maximum around 30 and $50 \mathrm{~m}$ was identified.

All regions with SSTs below the mean of $19.4^{\circ} \mathrm{C}$ are considered to be upwelling in the following sections for identi-
Table 1. Environmental parameters, as well as halocarbons in water, air and sea-to-air fluxes during the cruise. Means of sea surface temperature (SST), sea surface salinity (SSS) and wind speed are for 10 min averages. All data can be accessed at PANGAEA (Hepach et al., 2016).

\begin{tabular}{|c|c|c|c|}
\hline Parameter & & Unit & $\begin{array}{r}\text { Mean } \\
(\min -\max )\end{array}$ \\
\hline SST & & ${ }^{\circ} \mathrm{C}$ & $\begin{array}{r}19.4 \\
(15.0-22.4)\end{array}$ \\
\hline SSS & & & $\begin{array}{r}34.95 \\
(34.10-35.50)\end{array}$ \\
\hline TChl $a$ & & $\mu g \mathrm{~L}^{-1}$ & $\begin{array}{r}1.80 \\
(0.06-12.65)\end{array}$ \\
\hline Wind speed & & $\mathrm{ms}^{-1}$ & $\begin{array}{r}6.17 \\
(0.42-15.47)\end{array}$ \\
\hline \multirow[t]{3}{*}{$\mathrm{CHBr}_{3}$} & Water & $\mathrm{pmol} \mathrm{L}^{-1}$ & $\begin{array}{r}6.6 \\
(0.2-21.5)\end{array}$ \\
\hline & Air & ppt & $\begin{array}{r}2.9 \\
(1.5-5.9)\end{array}$ \\
\hline & Sea-to-air flux & $\mathrm{pmol} \mathrm{m}^{-2} \mathrm{~h}^{-1}$ & $\begin{array}{r}130 \\
(-550-2201)\end{array}$ \\
\hline \multirow[t]{3}{*}{$\mathrm{CH}_{2} \mathrm{Br}_{2}$} & Water & $\mathrm{pmol} \mathrm{L}^{-1}$ & $\begin{array}{r}4.3 \\
(0.2-12.7)\end{array}$ \\
\hline & Air & ppt & $\begin{array}{r}1.3 \\
(0.8-2.0)\end{array}$ \\
\hline & Sea-to-air flux & $\mathrm{pmol} \mathrm{m}^{-2} \mathrm{~h}^{-1}$ & $\begin{array}{r}273 \\
(-128-1321)\end{array}$ \\
\hline \multirow[t]{3}{*}{$\mathrm{CH}_{3} \mathrm{I}$} & Water & $\mathrm{pmol}^{-1}$ & $\begin{array}{r}9.8 \\
(1.1-35.4)\end{array}$ \\
\hline & Air & ppt & $\begin{array}{r}1.5 \\
(0.6-3.2)\end{array}$ \\
\hline & Sea-to-air flux & $\mathrm{pmol} \mathrm{m}^{-2} \mathrm{~h}^{-1}$ & $\begin{array}{r}954 \\
(21-4686)\end{array}$ \\
\hline \multirow[t]{3}{*}{$\mathrm{CH}_{2} \mathrm{ClI}$} & Water & $\mathrm{pmol} \mathrm{L}^{-1}$ & $\begin{array}{r}10.9 \\
(0.4-58.1)\end{array}$ \\
\hline & Air & ppt & $\begin{array}{r}0.4 \\
(0-2.5)\end{array}$ \\
\hline & Sea-to-air flux & $\mathrm{pmol} \mathrm{m}^{-2} \mathrm{~h}^{-1}$ & $\begin{array}{r}834 \\
(-28-5652)\end{array}$ \\
\hline \multirow[t]{3}{*}{$\mathrm{CH}_{2} \mathrm{I}_{2}$} & Water & $\mathrm{pmol} \mathrm{L}^{-1}$ & $\begin{array}{r}7.7 \\
(0.2-32.4)\end{array}$ \\
\hline & Air & $\mathrm{ppt}$ & $\begin{array}{r}0.2 \\
(0-3.3)\end{array}$ \\
\hline & Sea-to-air flux & $\mathrm{pmol} \mathrm{m}^{-2} \mathrm{~h}^{-1}$ & $\begin{array}{r}504 \\
(-126-2546)\end{array}$ \\
\hline
\end{tabular}

fying different significant regions for halocarbon production. Based on this criterion, four upwelling regions (I-IV) close to the coast were classified (Fig. 1). The most intense upwelling (lowest SSTs, high nutrient concentrations) appeared in the northernmost region of the cruise track, region I, while higher TChl $a$ and lower nutrients indicate a fully developed bloom in the southern part of the cruise (upwelling regions III and IV). Upwelling region II was characterized by a lower 
Table 2. Spearman's rank correlation coefficients of correlations of all halocarbon surface data with several ambient parameters, as well as biological proxies. Bold numbers indicate correlations that are significant at $p<0.05$ with a sample number of 107 for all environmental data and 46 for all phytoplankton and nutrient data considering all collocated surface data.

\begin{tabular}{|c|c|c|c|c|c|c|c|c|c|c|c|c|}
\hline & $\mathrm{CHBr}_{3}$ & $\mathrm{CH}_{2} \mathrm{Br}_{2}$ & $\mathrm{CH}_{3} \mathrm{I}$ & $\mathrm{CH}_{2} \mathrm{ClI}$ & $\mathrm{CH}_{2} \mathrm{I}_{2}$ & SST & SSS & $\begin{array}{l}\text { Global } \\
\text { radiation }\end{array}$ & Diatoms & $\begin{array}{r}\text { Crypto- } \\
\text { phytes }\end{array}$ & $\begin{array}{l}\text { Dino- } \\
\text { flagellates }\end{array}$ & TChl $a$ \\
\hline DIN : DIP & -0.26 & -0.34 & -0.38 & -0.30 & -0.32 & 0.00 & 0.41 & 0.13 & -0.18 & -0.17 & -0.10 & -0.08 \\
\hline TChl $a$ & 0.48 & 0.56 & 0.73 & 0.74 & 0.70 & -0.82 & -0.77 & -0.20 & 0.93 & 0.85 & 0.33 & \\
\hline $\begin{array}{l}\text { Dino- } \\
\text { flagellates }\end{array}$ & 0.15 & 0.28 & 0.15 & 0.17 & 0.21 & -0.23 & -0.22 & -0.01 & 0.38 & 0.26 & & \\
\hline $\begin{array}{l}\text { Crypto- } \\
\text { phytes }\end{array}$ & 0.38 & 0.54 & 0.61 & 0.61 & 0.64 & -0.74 & -0.79 & -0.18 & 0.73 & & & \\
\hline Diatoms & 0.58 & 0.58 & 0.73 & 0.79 & 0.72 & -0.76 & -0.72 & -0.18 & & & & \\
\hline $\begin{array}{l}\text { Global } \\
\text { radiation }\end{array}$ & 0.14 & -0.10 & -0.22 & -0.03 & -0.08 & 0.20 & 0.12 & & & & & \\
\hline SSS & -0.44 & -0.48 & -0.75 & -0.69 & -0.45 & 0.68 & & & & & & \\
\hline SST & -0.29 & -0.57 & -0.52 & -0.62 & -0.58 & & & & & & & \\
\hline $\mathrm{CH}_{2} \mathrm{I}_{2}$ & 0.60 & 0.43 & 0.66 & 0.59 & & & & & & & & \\
\hline $\mathrm{CH}_{2} \mathrm{ClI}$ & 0.64 & 0.70 & 0.83 & & & & & & & & & \\
\hline $\mathrm{CH}_{3} \mathrm{I}$ & 0.66 & 0.46 & & & & & & & & & & \\
\hline $\mathrm{CH}_{2} \mathrm{Br}_{2}$ & 0.56 & & & & & & & & & & & \\
\hline
\end{tabular}

DIN : DIP ratio in contrast to region I. SSS with a mean of 34.95 (34.10 and 35.50) is lowest in upwelling region IV, which is likely influenced by local river input such as the rivers Pisco, Cañete and Matagente, and may explain the observed low salinities due to enhanced fresh water input in boreal winter (Bruland et al., 2005).

\section{Halocarbons in the surface water and depth profiles during M91}

\subsection{Halocarbon distribution in surface water}

Measurements of halocarbons in the tropical eastern $\mathrm{Pa}$ cific are very sparse and no data were available for the Peruvian upwelling system before our campaign. Sea surface concentrations of $\mathrm{CHBr}_{3}$ and $\mathrm{CH}_{2} \mathrm{Br}_{2}$ with means of $6.6(0.2-21.5)$ and $4.3(0.2-12.7) \mathrm{pmol} \mathrm{L}^{-1}$, respectively, were measured during M91 (Table 1, Fig. 2). These values are low in comparison to $44.7 \mathrm{pmol} \mathrm{L}^{-1} \mathrm{CHBr}_{3}$ in tropical upwelling systems in the Atlantic, while our measurements of $\mathrm{CH}_{2} \mathrm{Br}_{2}$ compare better to these upwelling systems, from which maximum concentrations of $9.4 \mathrm{pmol} \mathrm{L}^{-1}$ were reported (Quack et al., 2007a; Carpenter et al., 2009; Hepach et al., 2014, 2015). $\mathrm{CHBr}_{3}\left(0.2-20.7 \mathrm{pmol} \mathrm{L}^{-1}\right)$ and $\mathrm{CH}_{2} \mathrm{Br}_{2}\left(0.7-6.5 \mathrm{pmol} \mathrm{L}^{-1}\right)$ concentrations in the tropical eastern Pacific open-ocean and Chilean coastal waters during a cruise from Punta Arenas, Chile, to Seattle, USA, in April 2010 (Liu et al., 2013) compare well with our data. The most elevated concentrations measured at the Chilean coast agree with our elevated northern coastal data. Some measurements also exist for the tropical West Pacific with on average 0.5 to 3 times our $\mathrm{CHBr}_{3}$ and 0.2 to 1 times our $\mathrm{CH}_{2} \mathrm{Br}_{2}$, with the high average originating from a campaign close to the coast with macroalgal and anthropogenic sources (Krüger and Quack, 2013; Fuhlbrügge et al., 2016b). $\mathrm{CHBr}_{3}$ and $\mathrm{CH}_{2} \mathrm{Br}_{2}$ have been suggested to have similar sources (Moore et al., 1996; Quack et al., 2007b). However, during our cruise, the correlation between the two compounds was comparatively weak $\left(r_{\mathrm{s}}=0.56\right)$, consistent with the findings of Liu et al. (2013), who ascribed the weaker correlation of these two compounds to formation in a common ecosystem rather than to the exact same biological sources. Maxima of $\mathrm{CH}_{2} \mathrm{Br}_{2}$ were observed in both upwelling regions III and IV, while $\mathrm{CHBr}_{3}$ was highest in the most southerly upwelling IV (Fig. 2).

While we found the Peruvian upwelling and the adjacent waters to be only a moderate source region for bromocarbons, iodocarbons were observed in high concentrations of $10.9(0.4-58.1), 9.8(1.1-35.4)$ and $7.7(0.2-32.4) \mathrm{pmol} \mathrm{L}^{-1}$ for $\mathrm{CH}_{2} \mathrm{ClI}, \mathrm{CH}_{3} \mathrm{I}$ and $\mathrm{CH}_{2} \mathrm{I}_{2}$, respectively (Table 1, Fig. 3a). These concentrations identify the Peruvian upwelling as a significant source region of iodocarbons, especially considering the very short lifetimes of $\mathrm{CH}_{2} \mathrm{I}_{2}(10 \mathrm{~min})$ and $\mathrm{CH}_{2} \mathrm{ClI}$ $(9 \mathrm{~h})$ in tropical surface water (Jones and Carpenter, 2005). Hotspots were upwelling regions III and, even more so, the less fresh upwelling of region IV (Figs. 2 and 3).

The occurrence of $\mathrm{CH}_{3} \mathrm{I}$ in the tropical oceans (up to $36.5 \mathrm{pmol} \mathrm{L}^{-1}$ ) has previously been attributed to a predominantly photochemical source (Richter and Wallace, 2004; Jones et al., 2010), explaining its global hotspots in the subtropical gyres and close to the tropical western boundaries of the continents (Ziska et al., 2013; Stemmler et al., 2014). Previous campaigns in the eastern Pacific obtained concentrations of up to 21.7 and $8.8 \mathrm{pmol} \mathrm{L}^{-1}$ (Butler et al., 2007), and around 1.0 to $1.5 \mathrm{pmol} \mathrm{L}^{-1}$ (Mahajan et al., 2012), but not directly in the upwelling. 

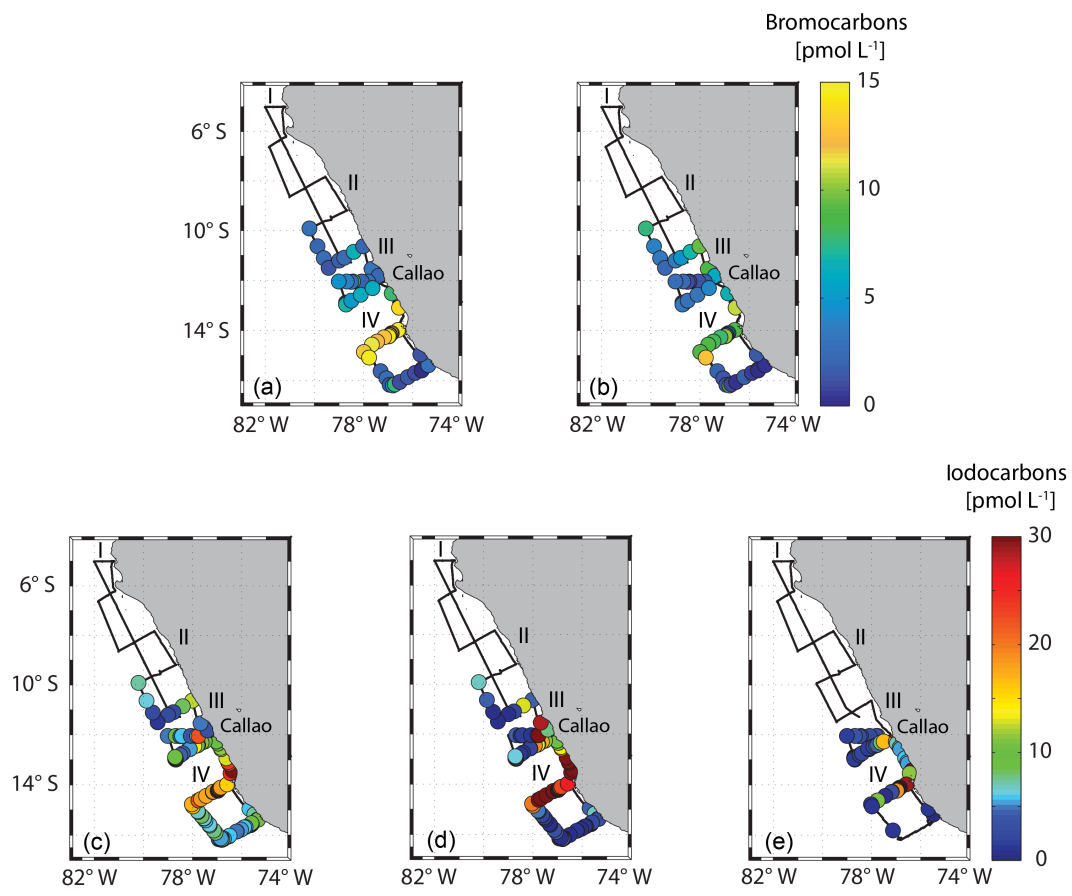

Figure 2. Halocarbon surface water measurements are shown in panels (a) and (b) for the bromocarbons (note the colour bar in the upper panel) with (a) $\mathrm{CHBr}_{3}$ and (b) $\mathrm{CH}_{2} \mathrm{Br}_{2}$. Iodocarbons can be found in panels (c-e) (note the colour bar in the lower panel) with (c) $\mathrm{CH}_{3} \mathrm{I}$, (d) $\mathrm{CH}_{2} \mathrm{ClI}$ and (e) $\mathrm{CH}_{2} \mathrm{I}_{2}$.

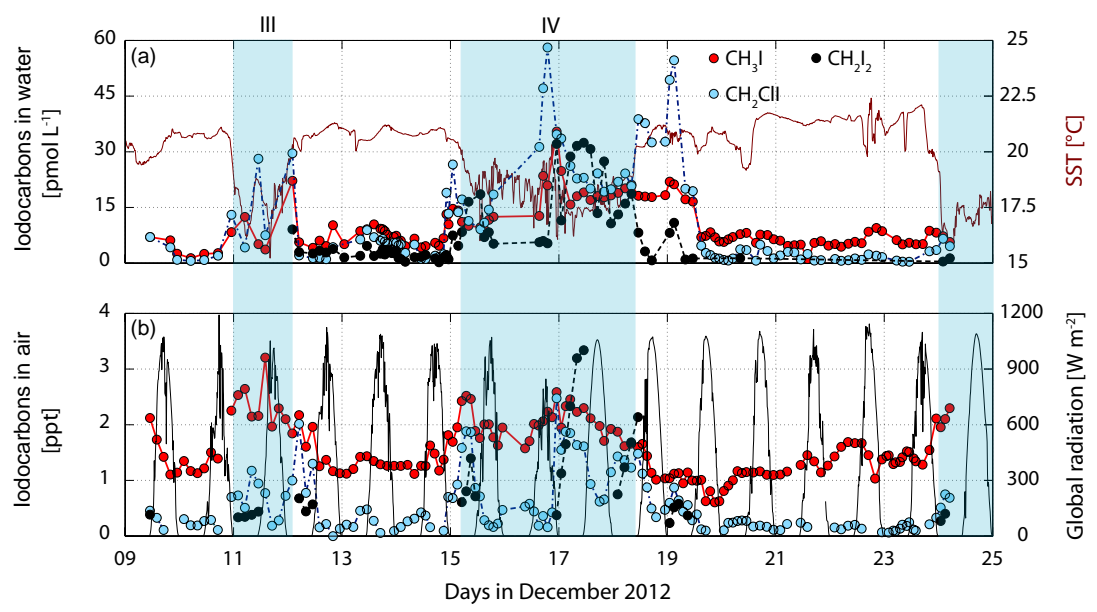

Figure 3. Surface water measurements of iodocarbons are presented in panel (a) with $\mathrm{CH}_{3} \mathrm{I}$ in red, $\mathrm{CH}_{2} \mathrm{ClI}$ in blue and $\mathrm{CH}_{2} \mathrm{I}_{2}$ in black on the left side along with SST (dark red) on the right side. Additionally, atmospheric mixing ratios of $\mathrm{CH}_{3} \mathrm{I}(\mathrm{red}), \mathrm{CH}_{2} \mathrm{ClI}_{(\mathrm{blue})}$ and $\mathrm{CH}_{2} \mathrm{I}_{2}$ (grey) on the left side together with global radiation (black, taken from pyranometer measurements referring to total shortwave radiation) on the right side are depicted in panel (b). Note that all times are in UTC.

No oceanic observations of $\mathrm{CH}_{2} \mathrm{ClI}$ and $\mathrm{CH}_{2} \mathrm{I}_{2}$ have been published so far for the tropical eastern Pacific. Concentrations of $\mathrm{CH}_{2} \mathrm{ClI}$ of up to $24.5 \mathrm{pmol} \mathrm{L}^{-1}$ were measured in the tropical and subtropical Atlantic Ocean (Abrahamsson et al., 2004; Chuck et al., 2005; Jones et al., 2010) and up to 17.1 pmol L $\mathrm{L}^{-1}$ for $\mathrm{CH}_{2} \mathrm{I}_{2}$ (Jones et al., 2010; Hepach et al., 2015), which is lower but in the range of our measurements from the Peruvian upwelling.
Correlations between the compounds indicate similar sources for all measured halocarbons, except for $\mathrm{CH}_{2} \mathrm{Br}_{2}$, with upwelling region IV as a hotspot area (Fig. 2). The strongest correlation was found for $\mathrm{CH}_{3} \mathrm{I}$ with $\mathrm{CH}_{2} \mathrm{ClI}\left(r_{\mathrm{s}}=\right.$ 0.83). $\mathrm{CH}_{2} \mathrm{I}_{2}$ and $\mathrm{CH}_{2} \mathrm{ClI}$ are often found to correlate very well with each other (Tokarczyk and Moore, 1994; Moore et al., 1996; Archer et al., 2007), which is usually attributed to the formation of $\mathrm{CH}_{2} \mathrm{ClI}$ during photolysis of $\mathrm{CH}_{2} \mathrm{I}_{2}$. In com- 


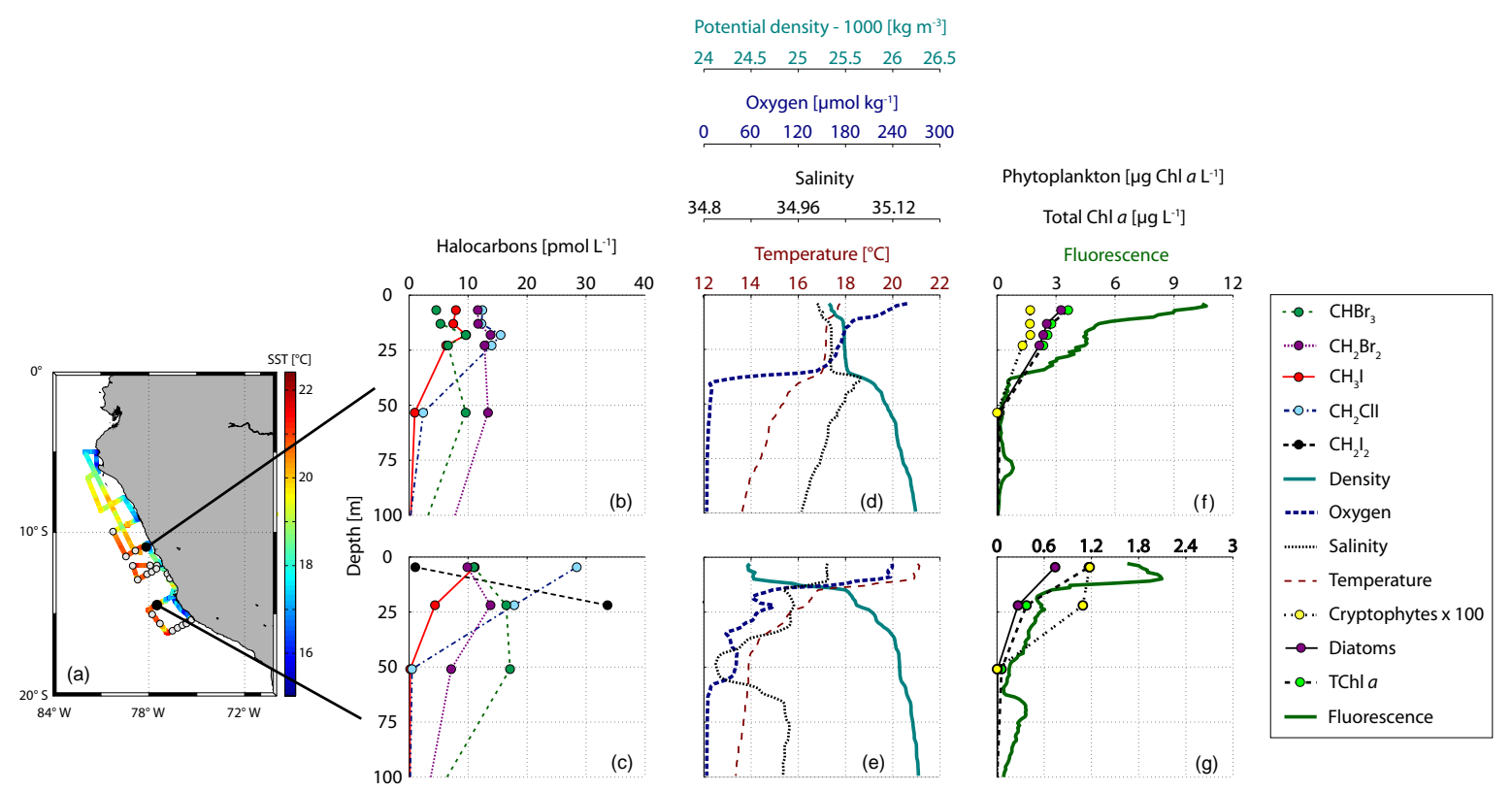

Figure 4. A cruise map including all CTD stations and SST is shown in panel (a), while selected depth profiles of iodocarbons and bromocarbons can be seen in panels (b-c), together with ambient parameters such as potential density (cyan), oxygen (dark blue), salinity (black) and temperature (dark red) in panels (d-e) and phytoplankton groups (cryptophytes and diatoms), total chlorophyll $a$ and fluorescence in panels (f-g). $\mathrm{CH}_{2} \mathrm{I}_{2}$ was undetectable at the first station (see also consistence with surface data). The data can be accessed at PANGAEA (Hepach et al., 2016).

parison, the weaker correlation between $\mathrm{CH}_{2} \mathrm{ClI}$ and $\mathrm{CH}_{2} \mathrm{I}_{2}$ $\left(r_{\mathrm{s}}=0.59\right)$ during our cruise may be the result of additional sources for $\mathrm{CH}_{2} \mathrm{ClI}$ (see also Sect. 5).

\subsection{Halocarbon distribution in depth profiles}

Depth profiles of halocarbons reveal maxima at the surface and around the Chl $a$ maximum, usually attributed to biological production of these compounds. $\mathrm{CHBr}_{3}$ and $\mathrm{CH}_{2} \mathrm{Br}_{2}$ profiles (Fig. 4a, b) showed distinct maxima in the deeper Chl $a$ maximum during a large part of the cruise, while some profiles were characterized by elevated concentrations in the surface usually associated with upwelling water. Both kinds of profiles are consistent with previous studies finding maxima in the deeper water column in the open ocean and surface maxima in upwelling regions (Yamamoto et al., 2001; Quack et al., 2004; Hepach et al., 2015). During the northern part of M91 (upwelling III), $\mathrm{CH}_{2} \mathrm{Br}_{2}$ in the water column was more elevated than $\mathrm{CHBr}_{3}$ (Fig. 4a), while $\mathrm{CHBr}_{3}$ was usually higher during the remaining part of the cruise (Fig. 4b).

Though most of the stations were characterized by subsurface maxima of iodocarbons, which were mostly located between 10 and $50 \mathrm{~m}$ (see example in Fig. 4, upper panel), surface maxima were often observed in upwelling region IV (see example in Fig. 4, lower panel), the region with highest iodocarbon concentrations. Profiles with surface maxima were generally characterized by much higher concentrations of these compounds, although we cannot completely exclude subsurface maxima at these locations owing to the sampling interval. $\mathrm{CH}_{2} \mathrm{I}_{2}$ was hardly detected in deeper water in the northern part of our measurements (Fig. 4, upper panel). Surface maxima in depth profiles of $\mathrm{CH}_{3} \mathrm{I}$ and $\mathrm{CH}_{2} \mathrm{ClI}$ were connected to surface maxima of several phytoplankton species, mainly diatoms $\left(r_{\mathrm{s}}=0.57\right.$ and 0.62$)$. Direct and indirect biological and photochemical formation are considered possible sources for these maxima. $\mathrm{CH}_{2} \mathrm{I}_{2}$ was usually strongly depleted in the surface in contrast to the deeper layers due to its rapid photolysis, which may also have been a source for surface $\mathrm{CH}_{2} \mathrm{ClI}$. Subsurface maxima occurred both below and within the mixed layer (see the example in Fig. 4d indicated by the temperature, salinity and density profiles). Maxima in the mixed layer probably appear because of very fast production (Hepach et al., 2015), while maxima below the mixed layer are supported by accumulation due to reduced mixing.

All five halocarbons were strongly depleted in waters below $50 \mathrm{~m}$. These deeper layers were also characterized by very low oxygen values, known as strong OMZ below the biologically active layers (Karstensen et al., 2008). A possible reason for the strong depletion of the halocarbons is their bacterially mediated reductive dehalogenation occurring under anaerobic conditions (Bouwer et al., 1981; Tanhua et al., 1996). 


\section{Relationship of surface halocarbons to environmental parameters}

Physical and chemical parameters as well as biological proxies such as TChl $a$ and phytoplankton group composition were investigated using correlation analysis in order to examine marine sources of halocarbons.

\subsection{Potential bromocarbon sources}

Bromocarbons were weakly but significantly anticorrelated with SSS and SST $\left(r_{\mathrm{s}}\right.$ between -0.29 and -0.57$)$, indicating sources in the upwelled water (Table 2). They showed a positive correlation with diatoms $\left(r_{\mathrm{s}}=0.58\right.$ for both compounds), the dominant phytoplankton group in the region. Diatoms have already been found to be involved in bromocarbon production in several laboratory and field studies (Tokarczyk and Moore, 1994; Moore et al., 1996; Quack et al., 2007b; Hughes et al., 2013). Thus, these findings are in agreement with current assumptions that this group may contribute directly or indirectly to bromocarbon production. During M91, $\mathrm{CH}_{2} \mathrm{Br}_{2}$ was more abundant in cooler, nutrientrich water than $\mathrm{CHBr}_{3}$, leading to a stronger correlation with TChl $a$ and SST, indicating an additional source associated with fresh upwelling. No significant correlations were found for bromocarbons with polysaccharidic DOM (Table 3), implying that DOM components analysed during the cruise were not involved in bromocarbon production, at least not in the upper water column. Bromocarbon production from DOM has also been suggested to be slow (Liu et al., 2015), which could shift larger bromocarbon concentrations to later times after our cruise.

\subsection{Iodinated compounds and phytoplankton}

In general, the iodocarbons correlated more strongly with biological parameters than the bromocarbons. Diatoms were found to correlate very strongly with all three iodocarbons $\left(r_{\mathrm{s}}=0.73\right.$ with $\mathrm{CH}_{3} \mathrm{I}, r_{\mathrm{s}}=0.79$ with $\mathrm{CH}_{2} \mathrm{ClI}$ and $\left.r_{\mathrm{s}}=0.72\right)$. Weak but significant anticorrelations with DIN:DIP and SST suggest that iodocarbons were associated with cool and slightly DIN depleted water. The occurrence of large amounts of iodocarbons seemed to be associated with an established diatom bloom. The production of $\mathrm{CH}_{3} \mathrm{I}, \mathrm{CH}_{2} \mathrm{ClI}$ and $\mathrm{CH}_{2} \mathrm{I}_{2}$ by a number of diatom species has been observed in several studies before (Moore et al., 1996; Manley and de la Cuesta, 1997), consistent with our findings. The very high correlation of cryptophytes with iodocarbons was likely based on the co-occurrence of these species with diatoms (Table 2 and description in Sect. 3).

\subsection{Iodinated compounds and DOM}

Correlations of the three iodinated compounds with polysaccharidic DOM components in subsurface water revealed a strong relationship of the iodocarbon abundance with
Table 3. Correlations of halocarbons with combined highmolecular-weight (HMW) carbohydrates (CCHO) and uronic acids (URA) from subsurface samples ( $\mathrm{T}$ - total; $\mathrm{d}$-dissolved; $\mathrm{P}$ - particulate) with a sample number of 29 for each variable. Bold numbers indicate significant correlations.

\begin{tabular}{lrrrrr}
\hline & $\mathrm{CHBr}_{3}$ & $\mathrm{CH}_{2} \mathrm{Br}_{2}$ & $\mathrm{CH}_{3} \mathrm{I}$ & $\mathrm{CH}_{2} \mathrm{ClI}$ & $\mathrm{CH}_{2} \mathrm{I}_{2}$ \\
\hline TCCHO & 0.15 & 0.28 & $\mathbf{0 . 7 8}$ & $\mathbf{0 . 8 2}$ & $\mathbf{0 . 6 6}$ \\
dCCHO & 0.39 & 0.48 & $\mathbf{0 . 8 2}$ & $\mathbf{0 . 9 0}$ & $\mathbf{0 . 5 5}$ \\
PCCHO & -0.06 & -0.10 & $\mathbf{0 . 6 1}$ & $\mathbf{0 . 6 4}$ & $\mathbf{0 . 6 8}$ \\
TURA & 0.31 & 0.34 & $\mathbf{0 . 8 3}$ & $\mathbf{0 . 8 8}$ & $\mathbf{0 . 5 2}$ \\
dURA & -0.18 & 0.42 & $\mathbf{0 . 4 8}$ & $\mathbf{0 . 7 9}$ & $\mathbf{0 . 5 0}$ \\
PURA & 0.37 & 0.22 & $\mathbf{0 . 8 4}$ & $\mathbf{0 . 8 4}$ & $\mathbf{0 . 5 4}$ \\
\hline
\end{tabular}

polysaccharides and in particular uronic acids (Table 3). $\mathrm{CH}_{3} \mathrm{I}$ and $\mathrm{CH}_{2} \mathrm{ClI}$ showed strong correlations with particulate uronic acids (both $\left.r_{\mathrm{s}}=0.84\right)$, total uronic acids $\left(r_{\mathrm{s}}=\right.$ 0.83 and 0.88$)$ and dissolved polysaccharides $\left(r_{\mathrm{s}}=0.82\right.$ and 0.90 ). The correlations of $\mathrm{CH}_{2} \mathrm{I}_{2}$ with polysaccharides were less strong but significant $\left(r_{\mathrm{s}}=0.68\right.$ with particulate, $r_{\mathrm{s}}=$ 0.66 with total and $r_{\mathrm{s}}=0.55$ with dissolved). The abovelisted DOM components were also significantly correlated to diatoms $\left(r_{\mathrm{s}}=0.68\right.$ with polysaccharides and $r_{\mathrm{s}}=0.75$ with uronic acids), which were a potential source for the accumulated organic matter in the subsurface. The exact composition of surface water DOM is determined by ecosystem compositions. Polysaccharides with uronic acids as an important constituent have for example been shown to contribute largely to the DOM pool in a diatom-rich region (Engel et al., 2012).

Hill and Manley (2009) tested several diatom species for their production of halocarbons in a laboratory study, and suggested that a major formation pathway for polyhalogenated compounds may actually not be from direct algal production but rather indirectly through their release of hypoiodous (HOI) and hypobromous acid $(\mathrm{HOBr})$, which then react with the present DOM (Lin and Manley, 2012; Liu et al., 2015). The formation of $\mathrm{HOI}$ and $\mathrm{HOBr}$ within the algae is enzymatic, with possible chloroperoxidase (CPO), BPO and iodoperoxidase (IPO) involvement. While CPO and BPO may produce both $\mathrm{HOBr}$ and HOI, IPO only leads to HOI. Moore et al. (1996) suggested that the occurrence of BPO and IPO in the phytoplankton cells may be highly speciesdependent. This leads to the assumption that diatoms abundant in the Peruvian upwelling contained more IPO than $\mathrm{BPO}$, which could explain the higher abundance of iodocarbons relative to bromocarbons during M91.

The formation of $\mathrm{CH}_{3} \mathrm{I}$ through DOM may be different than the production of $\mathrm{CH}_{2} \mathrm{ClI}$ and $\mathrm{CH}_{2} \mathrm{I}_{2}$. While $\mathrm{CH}_{2} \mathrm{I}_{2}$ is suggested to be formed via haloform-type reactions (Carpenter et al., 2005), $\mathrm{CH}_{3} \mathrm{I}$ is produced using a methyl-radical source (White, 1982). The relationship of $\mathrm{CH}_{3} \mathrm{I}$ with DOM can be the result of both photochemical and biological production pathways: DOM, which was observed in high concentrations in the biologically productive waters, can act as 
the methyl-radical source during photochemical production of $\mathrm{CH}_{3} \mathrm{I}$ (Bell et al., 2002). A second possible biological pathway of methyl iodide production takes place via bacteria and microalgae, which can utilize methyl transferases in their cells. HOI plays a significant role in this production pathway by providing the iodine to the methyl group (Yokouchi et al., 2014).

The Peruvian upwelling was a strong source for the iodocarbons $\mathrm{CH}_{3} \mathrm{I}, \mathrm{CH}_{2} \mathrm{ClI}$ and $\mathrm{CH}_{2} \mathrm{I}_{2}$ and a weaker source for the bromocarbons $\mathrm{CHBr}_{3}$ and $\mathrm{CH}_{2} \mathrm{Br}_{2}$. We propose a formation mechanism for this region as described in Fig. 5 based on measurements of short-lived halocarbons and biological parameters during M91. Diatoms, which can contain the necessary enzymes for halocarbon formation, were identified as an important source based on their strong correlations with the bromo- and iodocarbons and with polysaccharidic DOM. The very good correlations of iodocarbons with polysaccharides and uronic acids are an indicator that these DOM components may have been important substrates for iodocarbon production potentially produced from the present diatoms. The higher iodocarbon concentrations can likely be explained by phytoplankton species containing more IPO than BPO, leading to a stronger production of iodocarbons. Additionally, the particular type of DOM may also have regulated the production of specific halocarbons (Liu et al., 2015), in this case $\mathrm{CH}_{3} \mathrm{I}, \mathrm{CH}_{2} \mathrm{ClI}$ and $\mathrm{CH}_{2} \mathrm{I}_{2}$.

One interesting feature of our analysis is the fact that $\mathrm{CH}_{2} \mathrm{I}_{2}$, when compared to the other two iodocarbons, showed weaker correlations with the polysaccharides possibly due to its shorter surface water lifetime. Moreover, $\mathrm{CH}_{2} \mathrm{I}_{2}$ and $\mathrm{CH}_{2} \mathrm{ClI}$ showed weaker correlations in the Peruvian upwelling than during other cruises in the tropical Atlantic, namely MSM18/3 (Hepach et al., 2015) and DRIVE (Hepach et al., 2014). When combining the two arguments of a short $\mathrm{CH}_{2} \mathrm{I}_{2}$ lifetime and only a weak correlation between $\mathrm{CH}_{2} \mathrm{I}_{2}$ and $\mathrm{CH}_{2} \mathrm{CII}$, this may indicate an additional source for $\mathrm{CH}_{2} \mathrm{CII}$ similar to $\mathrm{CH}_{3} \mathrm{I}$, explaining why $\mathrm{CH}_{3} \mathrm{I}$ and $\mathrm{CH}_{2} \mathrm{CII}$ correlate much better with each other than with $\mathrm{CH}_{2} \mathrm{I}_{2}$.

\section{From the ocean to the atmosphere}

\subsection{Sea-to-air fluxes of iodocarbons}

Due to high oceanic iodocarbon concentrations measured in sea surface water of the Peruvian upwelling and despite the moderate prevailing wind speeds of $6.17(0.42-$ 15.47) $\mathrm{m} \mathrm{s}^{-1}$, high iodocarbon sea-to-air fluxes were calculated in contrast to the rather low bromocarbon emissions during our cruise (Fuhlbrügge et al., 2016a). The highest average fluxes of the three iodocarbons of 954 (214686) $\mathrm{pmol} \mathrm{m}^{-2} \mathrm{~h}^{-1}$ were calculated for $\mathrm{CH}_{3} \mathrm{I}$, followed by $834(-24-5652) \mathrm{pmol} \mathrm{m}^{-2} \mathrm{~h}^{-1}$ for $\mathrm{CH}_{2} \mathrm{ClI}$ and finally 504 (-126-2546) $\mathrm{pmol} \mathrm{m}^{-2} \mathrm{~h}^{-1}$ for $\mathrm{CH}_{2} \mathrm{I}_{2}$ (Table 1). These were on average 4 to 7 times higher than $\mathrm{CHBr}_{3}$ and 2 to

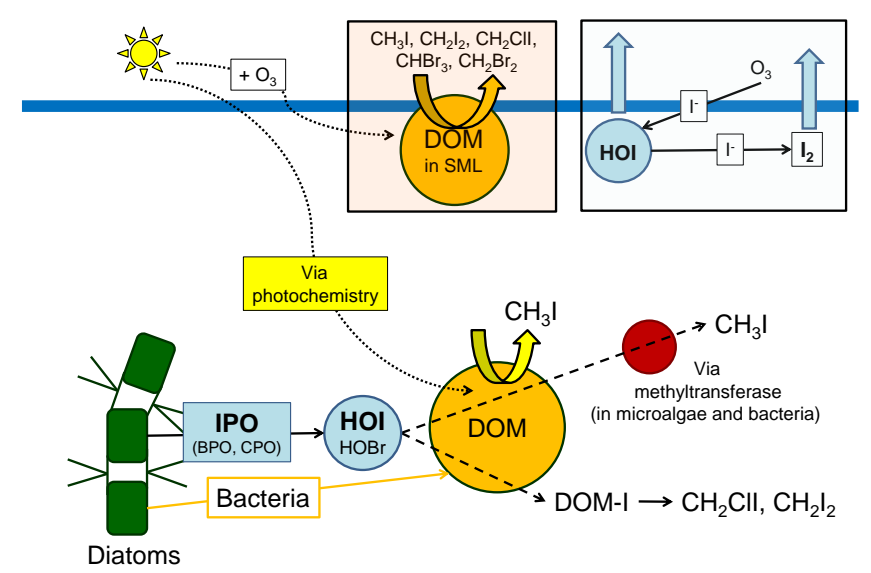

Figure 5. Proposed mechanisms for formation of iodocarbons - release of HOI with the help of iodoperoxiases (IPO), followed by reaction with DOM (dissolved organic matter (DOM) via iodine binding to DOM (DOM-I) to form $\mathrm{CH}_{2} \mathrm{ClI}$ and $\mathrm{CH}_{2} \mathrm{I}_{2}$. $\mathrm{CH}_{3} \mathrm{I}$ forms via photochemistry and/or biological formation via methyltransferases. The box indicates potential formation of halocarbons from DOM in the sea surface microlayer (SML) in addition to inorganic iodine sources there, shown by the light-blue box. For more information on the inorganic iodine chemistry in the SML, please refer to Carpenter et al. (2013).

4 times higher than the $\mathrm{CH}_{2} \mathrm{Br}_{2}$ sea-to-air fluxes during the cruise.

Our estimated fluxes of $\mathrm{CH}_{3} \mathrm{I}$ are in the range of emissions calculated for the tropical and subtropical Atlantic of 625 to 2154 pmol m$^{-2} \mathrm{~h}^{-1}$ (Chuck et al., 2005; Jones et al., 2010). Moore and Groszko (1999), who performed a study between $40^{\circ} \mathrm{N}$ and $40^{\circ} \mathrm{S}$ close to our investigation region but not covering the Peruvian upwelling, calculated on average $666 \mathrm{pmol} \mathrm{m}^{-2} \mathrm{~h}^{-1}$, which is 0.7 times our flux. Seato-air fluxes of $\mathrm{CH}_{2} \mathrm{ClI}$ from the same studies were reported to range on average between 250 and $1138 \mathrm{pmol} \mathrm{m}^{-2} \mathrm{~h}^{-1}$, with the largest fluxes originating from the Mauritanian upwelling region. These are 0.3 to 1.4 times the fluxes we calculated, showing that the Peruvian upwelling region is at the top end of oceanic $\mathrm{CH}_{2} \mathrm{ClI}$ emissions. We are only aware of two studies focusing on emissions of $\mathrm{CH}_{2} \mathrm{I}_{2}$ from the tropical Atlantic Ocean (Jones et al., 2010; Hepach et al., 2015); these studies show on average 0.2 and 1.4 times, respectively, the fluxes from the tropical eastern Pacific. The larger sea-to-air fluxes reported in Hepach et al. (2015) from the equatorial Atlantic cold tongue are mainly a result of much lower atmospheric mixing ratios there, increasing the concentration gradient, and additionally higher wind speeds, increasing the exchange coefficient $k_{\mathrm{w}}$.

In summary for this section, the large production of iodocarbons in the Peruvian upwelling led to enhanced emissions of these compounds to the troposphere despite very low wind speeds. An additional factor influencing halocarbon emissions is the low height and insolation of the MABL, 


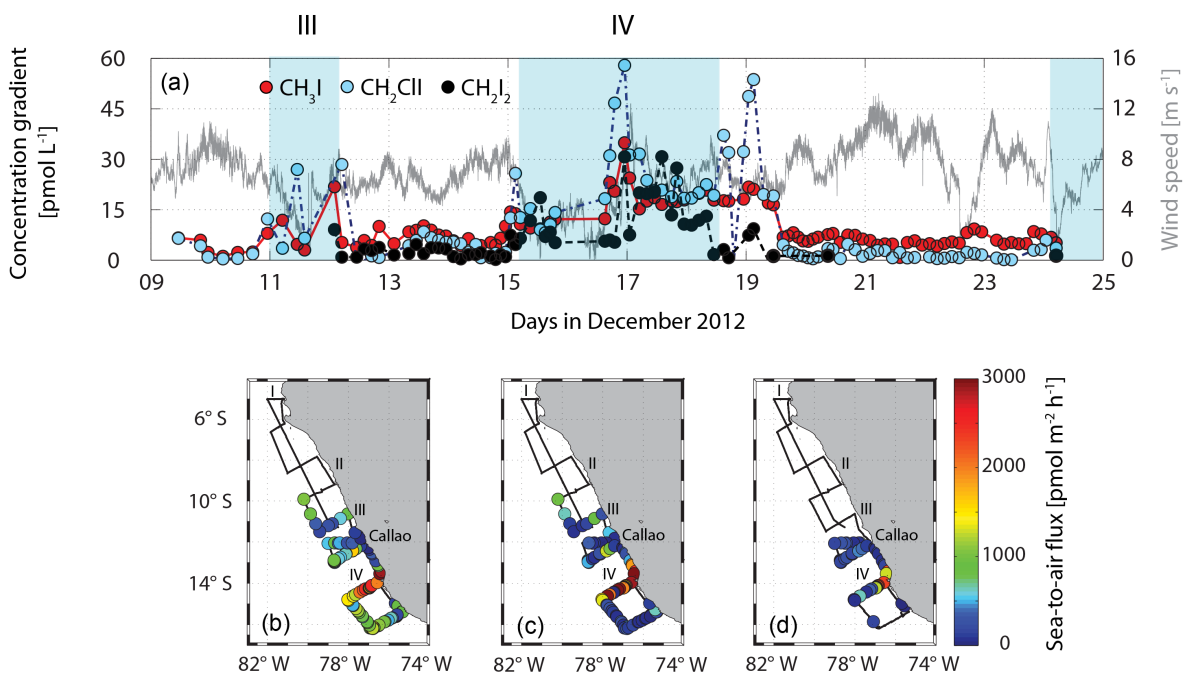

Figure 6. The concentration gradient of $\mathrm{CH}_{3} \mathrm{I}, \mathrm{CH}_{2} \mathrm{ClI}$ and $\mathrm{CH}_{2} \mathrm{I}_{2}$ along with wind speed (grey) is shown in panel (a), while the sea-to-air flux is depicted in panel (b) for $\mathrm{CH}_{3} \mathrm{I}$, (c) for $\mathrm{CH}_{2} \mathrm{ClI}$ and (d) for $\mathrm{CH}_{2} \mathrm{I}_{2}$. Note the colour bar on the right.
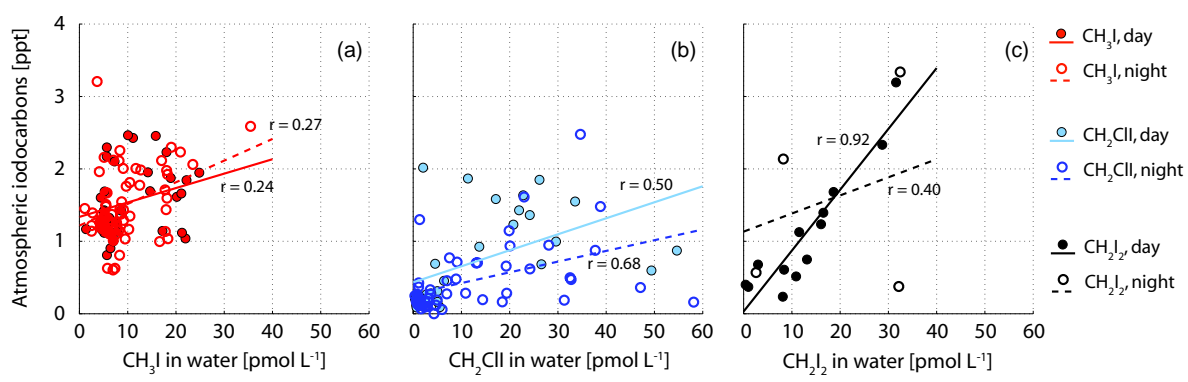

Figure 7. Atmospheric iodocarbons vs. oceanic iodocarbons for $\mathrm{CH}_{3} \mathrm{I}(\mathbf{a}), \mathrm{CH}_{2} \mathrm{ClI}$ (b) and $\mathrm{CH}_{2} \mathrm{I}_{2}$ (c), with the filled and open circles representing data obtained during the daytime and night-time, respectively, including least-squares lines (solid for day, dashed for night).

where halocarbons accumulate above the air-sea interface. The large sea-to-air fluxes and low wind speeds should result in high tropospheric iodocarbons, which was indeed observed and is discussed in the following section.

\subsection{Atmospheric iodocarbons}

Atmospheric mixing ratios of the three iodocarbons were elevated during M91, with up to $3.2 \mathrm{ppt}$ for $\mathrm{CH}_{3} \mathrm{I}$, up to $2.5 \mathrm{ppt}$ for $\mathrm{CH}_{2} \mathrm{CII}$ and up to $3.3 \mathrm{ppt}$ for $\mathrm{CH}_{2} \mathrm{I}_{2}$ (Table 1, Fig. 6), likely a result of the strong production and emissions of these compounds.

$\mathrm{CH}_{3} \mathrm{I}$ data were generally elevated in comparison to other eastern Pacific measurements of up to 1.1 to $2.1 \mathrm{ppt} \mathrm{CH}_{3} \mathrm{I}$ (Butler et al., 2007; Mahajan, et al., 2012), but lower than in the tropical central and eastern Atlantic around the equator, characterized by higher atmospheric $\mathrm{CH}_{3} \mathrm{I}$ of over $5 \mathrm{ppt}$ (Ziska et al., 2013). Gómez Martin et al. (2013) report 1.7 times higher maximum mixing ratios of $\mathrm{CH}_{3} \mathrm{I}$ of $5.4 \mathrm{ppt}$ from the Galápagos Islands, possibly rather influenced by very local sources around the measuring site, e.g. from sea- weed or macroalgae. Both $\mathrm{CH}_{2} \mathrm{ClI}$ and $\mathrm{CH}_{2} \mathrm{I}_{2}$ were also elevated in comparison to previous oceanic measurements, where, for example, 0.01 to $0.99 \mathrm{ppt} \mathrm{CH}_{2} \mathrm{ClI}$ was measured for remote locations in the Atlantic and Pacific (Chuck et al., 2005; Varner et al., 2008) and only up to $0.07 \mathrm{ppt}$ was reported for $\mathrm{CH}_{2} \mathrm{I}_{2}$ at a remote site in the Pacific (Yokouchi et al., 2011). Coastal areas with high macroalgal abundance were characterized by high $\mathrm{CH}_{2} \mathrm{ClI}$ of up to $3.4 \mathrm{ppt}$ (Varner et al., 2008) and up to 3.1 ppt $\mathrm{CH}_{2} \mathrm{I}_{2}$ (Carpenter et al., 1999; Peters et al., 2005), while 19.8 ppt (Peters et al., 2005) was measured at Mace Head, Ireland, and Lilia, France, in the North Atlantic.

The different atmospheric lifetimes of the three iodocarbons, ranging between 4 days $\left(\mathrm{CH}_{3} \mathrm{I}\right), 9 \mathrm{~h}\left(\mathrm{CH}_{2} \mathrm{ClI}\right)$ and 10 min $\left(\mathrm{CH}_{2} \mathrm{I}_{2}\right)$ (Carpenter and Reimann, 2014), partly explain the observed differences in their distributions. Although atmospheric $\mathrm{CH}_{3} \mathrm{I}$ was generally elevated in regions of high oceanic $\mathrm{CH}_{3} \mathrm{I}$ (Fig. 3) in upwelling regions III and IV, the atmospheric and oceanic data did not show a significant correlation. The $\mathrm{CH}_{3} \mathrm{I}$ lifetime of several days allows atmospheric 
$\mathrm{CH}_{3}$ I to mix within the MABL, possibly masking a correlation between local source regions and elevated mixing ratios.

The two shorter-lived iodinated compounds $\mathrm{CH}_{2} \mathrm{ClI}$ and $\mathrm{CH}_{2} \mathrm{I}_{2}$ generally showed a stronger influence of local marine sources. Both species correlate significantly with their oceanic concentrations with $r_{\mathrm{s}}=0.60\left(\mathrm{CH}_{2} \mathrm{ClI}\right)$ and $r_{\mathrm{s}}=$ $0.64\left(\mathrm{CH}_{2} \mathrm{I}_{2}\right)$. Oceanic $\mathrm{CH}_{2} \mathrm{ClI}$ and $\mathrm{CH}_{2} \mathrm{I}_{2}$ were emitted into the boundary layer, where they could accumulate during the night (see comparison with global radiation in Fig. 3b) and were rapidly degraded during the daytime via photolysis, which is their main sink in the troposphere (Carpenter and Reimann, 2014). This accumulation is especially apparent when the data are separated into "day" and "night" according to global radiation measurements, assuming that no radiation implies complete darkness. During the day, oceanic $\mathrm{CH}_{2} \mathrm{ClI}$ and $\mathrm{CH}_{2} \mathrm{I}_{2}$ correlate weakly with $r=0.5$ for $\mathrm{CH}_{2} \mathrm{ClI}$ and no significant correlation was found for $\mathrm{CH}_{2} \mathrm{I}_{2}(r=0.4)$, also owing to the fact that hardly any $\mathrm{CH}_{2} \mathrm{I}_{2}$ was measured during daylight. However, oceanic $\mathrm{CH}_{2} \mathrm{ClI}$ and $\mathrm{CH}_{2} \mathrm{I}_{2}$ correlate significantly with their atmospheric counterparts with $r=0.68$ and 0.92 in the night hours (Fig. 7). Moderate average wind speeds in the upwelling regions (Fig. 6) and stable atmospheric boundary layer conditions (Fuhlbrügge et al., 2016a) supported the accumulation of these compounds.

The Peruvian upwelling was in general characterized by elevated atmospheric iodocarbons as a result of their large sea-to-air fluxes caused by strong biological production. The upwelling could sustain elevated atmospheric levels of, for example, $\mathrm{CH}_{3} \mathrm{I}$, trapped iodocarbons and their degradation products in a stable MABL, and may have therefore contributed significantly to the tropospheric inorganic iodine budget, which is discussed in the following.

\subsection{Contributions to tropospheric iodine}

After their emission from the ocean and their chemical degradation in the marine boundary layer, iodocarbons contribute to the atmospheric inorganic iodine budget, $\mathrm{I}_{y}$. The importance of this contribution compared to abiotic sources is currently under debate and analysed for various oceanic environments (Mahajan et al., 2010; Großmann et al., 2013; Prados-Roman et al., 2015). So far, no correlations of IO with organic iodine precursor species have been observed (Großmann et al., 2013) and correlations between IO and Chl $a$ were often found to be negative (Mahajan et al., 2012; Gómez Martín et al., 2013). Chemical modelling studies, undertaken to explain the contributions of organic and inorganic oceanic iodine sources, showed in simulations that only a small fraction of the atmospheric IO stems from the organic precursors, with estimates of about $25 \%$ on a global average (Prados-Roman et al., 2015). Both arguments, the missing correlations and the small contributions, indicate that the organic source gas emissions play a minor role for the atmospheric iodine budget. Given the special conditions of the Peruvian upwelling with cold, nutrient-rich waters, the strong iodocarbon sources, and a stable MABL and trade inversion, it is of interest to analyse the local contributions to the atmosphere in this region and to compare with estimates from other oceanic environments.

We focus our analysis on the section of the cruise where MAX-DOAS measurements of IO and simultaneous iodocarbon measurements in the surface water and atmosphere were made (roughly south of $10^{\circ} \mathrm{S}$ ). Tropospheric vertical column densities (VCDs) of IO in the range of 2.5$6.0 \times 10^{12}$ molec. $\mathrm{cm}^{-2}$ were inferred from the MAX-DOAS measurements. Similar VCDs of IO were reported by Schönhardt et al. (2008) based on remote satellite measurements from SCIAMACHY, but VCDs around 1 order of magnitude higher were measured by Mahajan et al. (2012), which was, however, considerably further from the coast located than our measurements. Volume mixing ratios of IO along the cruise track (Fig. 8a) derived from the MAX-DOAS measurements show a pronounced variability and maxima close to upwelling regions II and IV. Daytime averaged IO volume mixing ratios are displayed in Fig. $8 \mathrm{~b}$ and range between 0.8 (on 12 and 22 December) and 1.5 ppt (on 26 December). Overall, the daytime IO abundance in the MABL above the Peruvian upwelling was relatively high compared to measurements from the nearby Galápagos Islands $(\sim 0.4 \mathrm{ppt})$ (Gómez Martín et al., 2013), and measurements closer to our investigation region with around between 0.2 and $0.6 \mathrm{ppt}$ in the MABL (Dix et al., 2013; Wang et al., 2015), as well as from other tropical oceans such as the Malaspina 2010 circumnavigation (0.4-1 ppt) (Prados-Roman et al., 2015). Other measurement campaigns such as the Cape Verde measurements (Read et al., 2008) and the TransBrom Sonne in the western Pacific (Großmann et al., 2013) found similar IO mixing ratios with values above $1 \mathrm{ppt}$, but significantly lower IO VCDs in the latter case. One of the first measurements of IO above the Peruvian upwelling was conducted by Volkamer et al. (2010), who report up to $3.5 \mathrm{ppt}$ in the region. These larger mixing ratios in comparison to our study are possibly due to even more enhanced biological production as the upwelling is more much more pronounced in October than in late December.

The M91 cruise track crisscrossed the waters between the coast and $200 \mathrm{~km}$ offshore multiple times, providing a comprehensive set of measurements over a confined area (see Fig. 8a) and allowing us to analyse the relation between IO and organic precursors. Assuming constant emissions over the cruise period we can link the oceanic sources with atmospheric IO observations at locations reached after hours to days of atmospheric transport. Therefore, we released FLEXPART trajectories from all sea surface measurement locations continuously over the whole measurement time period from 8 to 26 December loaded with the oceanic iodine as prescribed by the observed iodocarbon emissions. Based on the simulations of transport and chemical decay described in Sect. 2.5, we derived organic and inorganic iodine mixing ratios individually for each air parcel. Mixing with air 

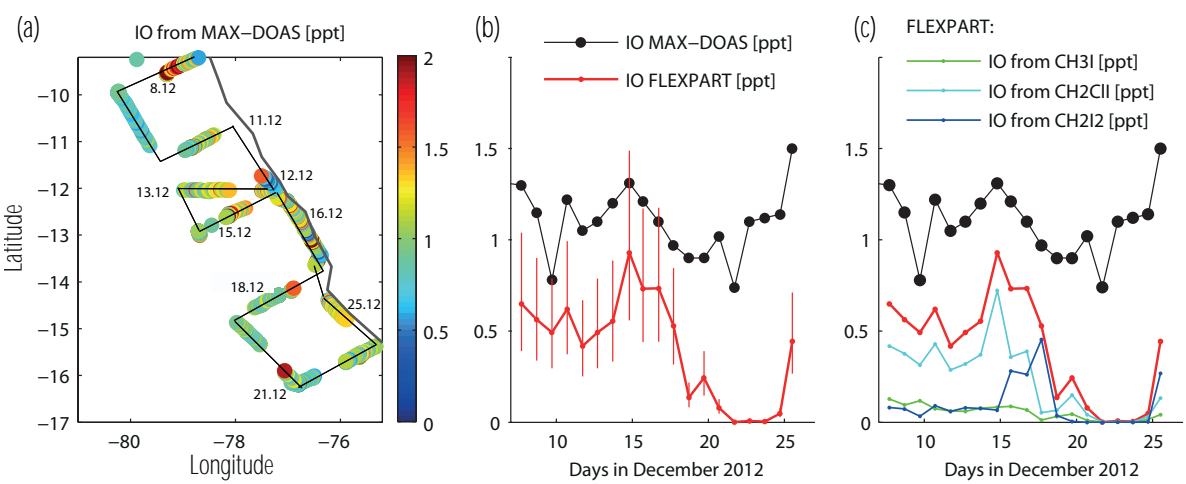

Figure 8. MAX-DOAS measurements of IO during the M91 campaign along the cruise track are shown in panel (a). Daytime averaged IO values from MAX-DOAS and coincident FLEXPART values are provided in panel (b). The vertical bars correspond to uncertainties associated with the inorganic iodine lifetime in the MABL (1-3 days) and the daytime fraction of IO to $\mathrm{I}_{y}(0.15$ to 0.3$)$. Contributions of the three oceanic iodocarbon sources to the modelled FLEXPART IO are also given in panel (c).

parcels impacted by other source regions was not taken into account. FLEXPART-based IO originating from organic precursors was derived as mean values over all air parcels in the MABL coinciding with the MAX-DOAS measurement locations within an area of $5 \mathrm{~km} \times 5 \mathrm{~km}$. Simplifying assumptions of a prescribed inorganic iodine lifetime ( 2 days) and IO to $\mathrm{I}_{y}$ ratio ( 0.15 to 0.3 ) were made to derive the IO mixing ratios. Uncertainties were estimated based on additional runs with varying atmospheric lifetime of inorganic iodine (1-3 days).

For the first part of the cruise from 8 to 18 December, FLEXPART-derived IO mixing ratio estimates at the MAXDOAS measurement locations (red line in Fig. $8 \mathrm{~b}$ and c) explain between 40 and $70 \%$ (55\% on average) of the measured IO assuming a lifetime for inorganic iodine of 2 days. As a consequence, about $0.5 \mathrm{ppt}$ of IO is expected to originate from other, likely inorganic, iodine sources. For the scenario of a shorter $\mathrm{I}_{y}$ lifetime (1 day), we find that the organic sources explain about $30 \%$ of the IO and for a relatively long lifetime ( 3 days), $80 \%$ can be explained. In general, the air masses were transported along the coast in the northwest direction and organic sources contribute to the IO budget along this transport path. Most of the IO results from $\mathrm{CH}_{2} \mathrm{ClI}$ (Fig. 8c) which was transported for some hours northwestwards (lifetime of $9 \mathrm{~h}$ ) before contributing to the atmospheric inorganic iodine budget.

For the second part of the cruise from 19 to 26 December, the amount of IO estimated from organic precursors was much smaller and often close to zero. This very small organic contribution was caused by two facts. First, the instantaneous sources during the last part of the cruise were much smaller (Fig. 6b-d), and second, sources situated further southwards, which also influence the iodine abundance in the cruise track region, were not analysed and thus not included in the simulations. Because of missing information on the source strength and distribution southwards of the cruise track, a proper comparison is only possible for the first part of the cruise before 19 December. However, given that the MAX-DOAS measurements of IO remained relatively high during the second part of the cruise, it is likely that additional significant organic iodine sources existed further southwards. This assumption is also supported by the fact that atmospheric $\mathrm{CH}_{3} \mathrm{I}$ mixing ratios remained relatively high during the second part of the cruise (50\% compared to the earlier part; see Fig. 3b), while the water concentrations were close to zero. Consequently, a source region of $\mathrm{CH}_{3} \mathrm{I}$ must have existed further southwards, contributing to the observed mixing ratios of $\mathrm{CH}_{3} \mathrm{I}$ and $\mathrm{IO}$ after some hours to days of atmospheric transport.

While the contribution of organic iodine to IO during the first part of the cruise is considerably higher than found in other regions, the amount of inorganic iodine precursors necessary to explain total IO $(0.5 \mathrm{ppt})$ is very similar to that derived in other studies (Prados-Roman et al., 2015). The higher organic contribution was consistent with the fact that there was an overall higher IO abundance compared to most other campaigns. Instantaneous IO and organic source gas emissions during M91 were not directly correlated. However, taking the transport within the first hours and days into account enables us to explain part of the atmospheric IO variations with the oceanic organic sources (Fig. 8b). We conclude that, for the first part of the cruise ( 8 to 18 December), the Peruvian upwelling region with higher iodocarbon sources leads to larger IO abundances, while the absolute inorganic contribution is similar to other regions. For the second part of the cruise (19 to 26 December), the organic contribution is considerably smaller; however, it cannot be fully estimated due to missing information on the sources southwards of the cruise track. 


\section{Conclusions}

The Peruvian upwelling at the western coast of South America was characterized for halocarbons for the first time during the M91 cruise. We measured moderate concentrations of the bromocarbons $\mathrm{CHBr}_{3}$ and $\mathrm{CH}_{2} \mathrm{Br}_{2}$, while we observed exceptionally high concentrations of the iodocarbons $\mathrm{CH}_{3} \mathrm{I}$, $\mathrm{CH}_{2} \mathrm{ClI}$ and $\mathrm{CH}_{2} \mathrm{I}_{2}$ in the surface seawater.

$\mathrm{CHBr}_{3}$ and $\mathrm{CH}_{2} \mathrm{Br}_{2}$ were significantly correlated with TChl $a$ and diatoms, suggesting biological formation of these compounds. Higher correlations of diatoms were found with the three iodocarbons, and even stronger correlations of the iodocarbons with the DOM components polysaccharides and uronic acids were observed. The polyhalogenated compounds $\mathrm{CH}_{2} \mathrm{ClI}$ and $\mathrm{CH}_{2} \mathrm{I}_{2}$ were potentially formed via these DOM components with the likely involvement of diatoms. $\mathrm{CH}_{3} \mathrm{I}$ may have been formed via photochemistry from the large pool of observed DOM and/or biologically via methyl transferases in microalgae and bacteria. The production of iodocarbons from DOM via the proposed mechanisms seems to have exceeded the bromocarbon production in the region in contrast to several previous studies in tropical Atlantic upwelling regions (Hepach et al., 2014, 2015).

Depth profiles showed subsurface maxima, common in the open ocean, and very pronounced and elevated surface maxima in regions of highest underway iodocarbon concentrations. The surface water was always depleted in $\mathrm{CH}_{2} \mathrm{I}_{2}$ with respect to the underlying water column due to its very rapid photolysis. The OMZ at depth was strongly depleted in all five measured halocarbons, suggesting an effective sink in the oxygen-depleted waters.

The high oceanic iodocarbon concentrations and elevated emissions also led to elevated atmospheric mixing ratios in the marine boundary layer. Atmospheric $\mathrm{CH}_{2} \mathrm{ClI}$ and $\mathrm{CH}_{2} \mathrm{I}_{2}$ showed clear diurnal cycles, accumulating during night-time and decreasing rapidly during daytime. Despite previous suggestions that the tropospheric iodine loading is mainly a product from direct emission of $\mathrm{HOI}$ and $\mathrm{I}_{2}$, we calculated important contributions of iodocarbons to the observed IO levels. Using FLEXPART, for the first part of the cruise we estimated a contribution of combined iodocarbon fluxes to IO of 30 to $80 \%$ assuming an inorganic iodine lifetime of between 1 and 3 days. This contribution of organoiodine is much higher than previously assumed (Prados-Roman et al., 2015), suggesting that iodocarbons therefore may contribute significantly to tropospheric iodine levels in regions of strong iodocarbon production mediated by phytoplankton (diatoms) and bacteria. For the second part of the cruise, the organic input to atmospheric IO levels is considerably smaller. Note, however, that unknown sources southwards of the cruise track are not taken into account and might enhance the estimated contribution. Atmospheric $\mathrm{CH}_{3} \mathrm{I}$ concentrations during the cruise were on average larger, at $1.5 \mathrm{ppt}$, than in most other oceanic regions. However, deep convective and subsequent slow transport is not expected to bring more than a few percent of the boundary layer $\mathrm{CH}_{3} \mathrm{I}$ concentrations up to the cold point (Tegtmeier et al., 2013). Therefore, the direct contribution of $\mathrm{CH}_{3} \mathrm{I}$ to stratospheric iodine is, although not negligible, expected to be smaller than the $0.2-0.7 \mathrm{ppt}$ estimated for inorganic iodine injections (SaizLopez et al., 2015).

Our observations reveal several uncertainties which need to be addressed in the future to better constrain the halocarbon budget and understand its role in a changing climate. Further studies of upwelling regions need to be performed in different seasons and years, since these regions are impacted by synoptic and climatic conditions, which are expected to have an impact on the strength of halocarbon emissions. Regular monitoring and a better knowledge of halocarbon sources and emissions are severely needed, since these have numerous implications for atmospheric processes such as ozone chemistry and aerosol formation, which have been investigated in several atmospheric modelling studies. These studies have mostly applied Chl $a$ as a proxy for halocarbon emissions. However, the potential involvement of DOM in the production of both iodo- and bromocarbons and the often weak correlation to Chl $a$ in the field raises the question of whether Chl $a$ is a suitable parameter to estimate halocarbon concentrations. Laboratory studies are therefore crucial to help in identifying more adequate parameters for predicting halocarbons in the ocean. Associated with the involvement of DOM in iodocarbon production is the occurrence of the relevant DOM components in large concentrations in the sea surface microlayer (SML) (Engel and Galgani, 2016a). The SML has been shown to cover a wide range of oceanic regions (Wurl et al., 2011), which could represent a significant additional source to atmospheric iodocarbons. The potential of the SML to produce $\mathrm{CH}_{2} \mathrm{I}_{2}$ has been previously suggested by Martino et al. (2009), who proposed that HOI converted from iodide in the SML may react with the present DOM, which may apply to $\mathrm{CH}_{2} \mathrm{ClI}$ and $\mathrm{CH}_{3} \mathrm{I}$ as well. Furthermore, the SML is in direct contact to the atmosphere, and the direct exposure to light may enhance halocarbon emissions (see also Fig. 5). The influence of these halocarbon emissions on the tropospheric halogen loading is still very much under debate, and our results underline the importance of constraining the actual contribution of these compounds to tropospheric halogen chemistry.

\section{Data availability}

Data for the M91 cruise is available at PANGAEA at https:// doi.pangaea.de/10.1594/PANGAEA.864787 (Hepach et al., 2016). For further data, please contact the authors.

Acknowledgements. We thank the chief scientist of cruise M91, Hermann Bange, as well as the captain and the crew of the R/V METEOR for their support. We would like to acknowledge Sonja Wiegmann for pigment analysis, Kerstin Nachtigall for nu- 
trient measurements, and Stefan Raimund and Sebastian Flöter for helping with halocarbon measurements. This work was part of the German research projects SOPRAN II (grant no. FKZ 03F0611A) and III (grant no. FKZ 03F0662A) funded by the Bundesministerium für Bildung und Forschung (BMBF). Astrid Bracher's contribution was funded by the Total Foundation project "Phytoscope". Finally, we would like to acknowledge the reviewers and the editor for very helpful input during the review process.

Edited by: R. Volkamer

Reviewed by: two anonymous referees

\section{References}

Abrahamsson, K., Lorén, A., Wulff, A., and Wangberg, S. A.: Airsea exchange of halocarbons: The influence of diurnal and regional variations and distribution of pigments, Deep-Sea Res. Pt. II, 51, 2789-2805, doi:10.1016/j.dsr2.2004.09.005, 2004.

Amachi, S.: Microbial contribution to global iodine cycling: Volatilization, accumulation, reduction, oxidation, and sorption of iodine, Microbes Environ., 23, 269-276, doi:10.1264/jsme2.ME08548, 2008.

Amachi, S., Kamagata, Y., Kanagawa, T., and Muramatsu, Y.: Bacteria mediate methylation of iodine in marine and terrestrial environments, Appl. Environ. Microb., 67, 2718-2722, doi:10.1128/aem.67.6.2718-2722.2001, 2001.

Archer, S. D., Goldson, L. E., Liddicoat, M. I., Cummings, D. G., and Nightingale, P. D.: Marked seasonality in the concentrations and sea-to-air flux of volatile iodocarbon compounds in the western English channel, J. Geophys. Res.-Oceans, 112, C08009, doi:10.1029/2006jc003963, 2007.

Bakun, A. and Weeks, S. J.: The marine ecosystem off Peru: What are the secrets of its fishery productivity and what might its future hold?, Prog. Oceanogr., 79, 290-299, doi:10.1016/j.pocean.2008.10.027, 2008.

Bange, H. W.: Surface ocean - lower atmosphere study (solas) in the upwelling region of peru, DFG-Senatskommission für Ozeanographie, Bremerhaven, 60 pp., doi:10.2312/cr_m91, 2013.

Barlow, R. G., Cummings, D. G., and Gibb, S. W.: Improved resolution of mono- and divinyl chlorophylls $\mathrm{a}$ and $\mathrm{b}$ and zeaxanthin and lutein in phytoplankton extracts using reverse phase c- $8 \mathrm{hplc}$, Mar. Ecol.-Prog. Ser., 161, 303-307, doi:10.3354/meps161303, 1997.

Bell, N., Hsu, L., Jacob, D. J., Schultz, M. G., Blake, D. R., Butler, J. H., King, D. B., Lobert, J. M., and Maier-Reimer, E.: Methyl iodide: Atmospheric budget and use as a tracer of marine convection in global models, J. Geophys. Res.-Atmos., 107, 4340, doi:10.1029/2001jd001151, 2002.

Bouwer, E. J., Rittmann, B. E., and McCarty, P. L.: Anaerobic degradation of halogenated 1- and 2-carbon organic compounds, Environ. Sci. Technol., 15, 596-599, doi:10.1021/es00087a012, 1981.

Brownell, D. K., Moore, R. M., and Cullen, J. J.: Production of methyl halides by Prochlorococcus and Synechococcus, Global Biogeochem. Cy., 24, GB2002, doi:10.1029/2009gb003671, 2010.
Bruland, K. W., Rue, E. L., Smith, G. J., and DiTullio, G. R.: Iron, macronutrients and diatom blooms in the Peru upwelling regime: Brown and blue waters of Peru, Mar. Chem., 93, 81-103, doi:10.1016/j.marchem.2004.06.011, 2005.

Burkholder, J. B., Curtius, J., Ravishankara, A. R., and Lovejoy, E. R.: Laboratory studies of the homogeneous nucleation of iodine oxides, Atmos. Chem. Phys., 4, 19-34, doi:10.5194/acp-419-2004, 2004.

Butler, J. H., King, D. B., Lobert, J. M., Montzka, S. A., YvonLewis, S. A., Hall, B. D., Warwick, N. J., Mondeel, D. J., Aydin, M., and Elkins, J. W.: Oceanic distributions and emissions of short-lived halocarbons, Global Biogeochem. Cy., 21, GB1023, doi:10.1029/2006gb002732, 2007.

Carpenter, L. J. and Reimann, S.: Ozone-depleting substances (odss) and other gases of interest to the Montreal protocol, chap. 1 in Scientific Assessment of Ozone Depletion, World Meteorological Institution (WMO), Geneva, Switzerland, Report No. 55, 2014.

Carpenter, L. J., Sturges, W. T., Penkett, S. A., Liss, P. S., Alicke, B., Hebestreit, K., and Platt, U.: Short-lived alkyl iodides and bromides at Mace Head, Ireland: Links to biogenic sources and halogen oxide production, J. Geophys. Res.-Atmos., 104, 16791689, 1999.

Carpenter, L. J., Hopkins, J. R., Jones, C. E., Lewis, A. C., Parthipan, R., Wevill, D. J., Poissant, L., Pilote, M., and Constant, P.: Abiotic source of reactive organic halogens in the sub-arctic atmosphere?, Environ. Sci. Technol., 39, 8812-8816, doi:10.1021/es050918w, 2005.

Carpenter, L. J., Jones, C. E., Dunk, R. M., Hornsby, K. E., and Woeltjen, J.: Air-sea fluxes of biogenic bromine from the tropical and North Atlantic Ocean, Atmos. Chem. Phys., 9, 1805-1816, doi:10.5194/acp-9-1805-2009, 2009.

Carpenter, L. J., MacDonald, S. M., Shaw, M. D., Kumar, R., Saunders, R. W., Parthipan, R., Wilson, J., and Plane, J. M. C.: Atmospheric iodine levels influenced by sea surface emissions of inorganic iodine, Nat. Geosci., 6, 108-111, doi:10.1038/ngeo1687, 2013.

Chavez, F. P., Bertrand, A., Guevara-Carrasco, R., Soler, P., and Csirke, J.: The northern Humboldt current system: Brief history, present status and a view towards the future, Prog. Oceanogr., 79, 95-105, doi:10.1016/j.pocean.2008.10.012, 2008.

Chuck, A. L., Turner, S. M., and Liss, P. S.: Oceanic distributions and air-sea fluxes of biogenic halocarbons in the open ocean, J. Geophys. Res.-Oceans, 110, C10022, doi:10.1029/2004jc002741, 2005.

Clémer, K., Van Roozendael, M., Fayt, C., Hendrick, F., Hermans, C., Pinardi, G., Spurr, R., Wang, P., and De Mazière, M.: Multiple wavelength retrieval of tropospheric aerosol optical properties from MAXDOAS measurements in Beijing, Atmos. Meas. Tech., 3, 863-878, doi:10.5194/amt-3-863-2010, 2010.

Czeschel, R., Stramma, L., Weller, R. A., and Fischer, T.: Circulation, eddies, oxygen, and nutrient changes in the eastern tropical South Pacific Ocean, Ocean Sci., 11, 455-470, doi:10.5194/os11-455-2015, 2015.

Dee, D. P., Uppala, S. M., Simmons, A. J., Berrisford, P., Poli, P., Kobayashi, S., Andrae, U., Balmaseda, M. A., Balsamo, G., Bauer, P., Bechtold, P., Beljaars, A. C. M., van de Berg, L., Bidlot, J., Bormann, N., Delsol, C., Dragani, R., Fuentes, M., Geer, A. J., Haimberger, L., Healy, S. B., Hersbach, H., Hólm, E. V., 
Isaksen, L., Kållberg, P., Köhler, M., Matricardi, M., McNally, A. P., Monge-Sanz, B. M., Morcrette, J. J., Park, B. K., Peubey, C., de Rosnay, P., Tavolato, C., Thépaut, J. N., and Vitart, F.: The era-interim reanalysis: Configuration and performance of the data assimilation system, Q. J. Roy. Meteor. Soc., 137, 553-597, doi:10.1002/qj.828, 2011.

Dix, B., Baidara, S., Bresch, J. F., Hall, S. R., Schmidt, K. S., Wang, S. Y., and Volkamer, R.: Detection of iodine monoxide in the tropical free troposphere, P. Natl. Acad. Sci. USA, 110, 20352040, doi:10.1073/pnas.1212386110, 2013.

Echevin, V., Aumont, O., Ledesma, J., and Flores, G.: The seasonal cycle of surface chlorophyll in the Peruvian upwelling system: A modelling study, Prog. Oceanogr., 79, 167-176, doi:10.1016/j.pocean.2008.10.026, 2008.

Engel, A. and Galgani, L.: The organic sea-surface microlayer in the upwelling region off the coast of Peru and potential implications for air-sea exchange processes, Biogeosciences, 13, 989-1007, doi:10.5194/bg-13-989-2016, 2016a.

Engel, A. and Händel, N.: A novel protocol for determining the concentration and composition of sugars in particulate and in high molecular weight dissolved organic matter (hmw-dom) in seawater, Mar. Chem., 127, 180-191, doi:10.1016/j.marchem.2011.09.004, 2011.

Engel, A., Händel, N., Wohlers, J., Lunau, M., Grossart, H. P., Sommer, U., und Riebesell, U.: Effects of sea surface warming on the production and composition of dissolved organic matter during phytoplankton blooms: results from a mesocosm study, J. Plankton Res., 33, 357-372, doi:10.1093/plankt/fbq122, 2011.

Engel, A., Harlay, J., Piontek, J., and Chou, L.: Contribution of combined carbohydrates to dissolved and particulate organic carbon after the spring bloom in the northern bay of biscay (north-eastern atlantic ocean), Cont. Shelf Res., 45, 42-53, doi:10.1016/j.csr.2012.05.016, 2012.

Frieß, U., Monks, P. S., Remedios, J. J., Rozanov, A., Sinreich, R., Wagner, T., and Platt, U.: Max-doas o4 measurements: A new technique to derive information on atmospheric aerosols: 2. Modeling studies, J. Geophys. Res.-Atmos., 111, D14203, doi:10.1029/2005JD006618, 2006.

Fuhlbrügge, S., Quack, B., Atlas, E., Fiehn, A., Hepach, H., and Krüger, K.: Meteorological constraints on oceanic halocarbons above the Peruvian upwelling, Atmos. Chem. Phys., 16, 1220512217, doi:10.5194/acp-16-12205-2016, 2016 a.

Fuhlbrügge, S., Quack, B., Tegtmeier, S., Atlas, E., Hepach, H., Shi, Q., Raimund, S., and Krüger, K.: The contribution of oceanic halocarbons to marine and free tropospheric air over the tropical West Pacific, Atmos. Chem. Phys., 16, 7569-7585, doi:10.5194/acp-16-7569-2016, 2016 b.

Fuse, H., Inoue, H., Murakami, K., Takimura, O., and Yamaoka, Y.: Production of free and organic iodine by roseovarius spp, FEMS Microbiol. Lett., 229, 189-194, doi:10.1016/s03781097(03)00839-5, 2003.

Gómez Martín, J. C. G., Mahajan, A. S., Hay, T. D., Prados-Roman, C., Ordonez, C., MacDonald, S. M., Plane, J. M. C., Sorribas, M., Gil, M., Mora, J. F. P., Reyes, M. V. A., Oram, D. E., Leedham, E., and Saiz-Lopez, A.: Iodine chemistry in the Eastern Pacific marine boundary layer, J. Geophys. Res.-Atmos., 118, 887-904, doi:10.1002/jgrd.50132, 2013.

Großmann, K., Frieß, U., Peters, E., Wittrock, F., Lampel, J., Yilmaz, S., Tschritter, J., Sommariva, R., von Glasow, R., Quack,
B., Krüger, K., Pfeilsticker, K., and Platt, U.: Iodine monoxide in the Western Pacific marine boundary layer, Atmos. Chem. Phys., 13, 3363-3378, doi:10.5194/acp-13-3363-2013, 2013.

Gschwend, P. M., Macfarlane, J. K., and Newman, K. A.: Volatile halogenated organic compounds released to seawater from temperate marine macroalgae, Science, 227, 1033-1035, doi:10.1126/science.227.4690.1033, 1985.

Hansell, D. A.: Recalcitrant dissolved organic carbon fractions, Ann. Rev. Mar. Sci., 5, 421-445, doi:10.1146/annurev-marine120710-100757, 2013.

Hepach, H., Quack, B., Ziska, F., Fuhlbrügge, S., Atlas, E. L., Krüger, K., Peeken, I., and Wallace, D. W. R.: Drivers of diel and regional variations of halocarbon emissions from the tropical North East Atlantic, Atmos. Chem. Phys., 14, 1255-1275, doi:10.5194/acp-14-1255-2014, 2014.

Hepach, H., Quack, B., Raimund, S., Fischer, T., Atlas, E. L., and Bracher, A.: Halocarbon emissions and sources in the equatorial Atlantic Cold Tongue, Biogeosciences, 12, 6369-6387, doi:10.5194/bg-12-6369-2015, 2015.

Hepach, H., Quack, B., Tegtmeier, S., Engel, A., Bracher, A., Fuhlbrügge, S., Galgani, L., Atlas, E., Lampel, J., Frieß, U., and Krüger, K.: Biogenic halocarbons from the Peruvian upwelling region during METEOR cruise M91, doi:10.1594/PANGAEA.864787, 2016.

Hill, V. L. and Manley, S. L.: Release of reactive bromine and iodine from diatoms and its possible role in halogen transfer in polar and tropical oceans, Limnol. Oceanogr., 54, 812-822, doi:10.4319/lo.2009.54.3.0812, 2009.

Hönninger, G.: Halogen oxide studies in the boundary layer by multi axis differential optical absorption spectroscopy and active longpath-doas, $\mathrm{PhD}$ thesis, Institut für Umweltphysik, Universität Heidelberg, Heidelberg, Germany, 2002.

Hossaini, R., Chipperfield, M. P., Montzka, S. A., Rap, A., Dhomse, S., and Feng, W.: Efficiency of short-lived halogens at influencing climate through depletion of stratospheric ozone, Nat. Geosci., 8, 186-190, doi:10.1038/ngeo2363, 2015.

Hughes, C., Franklin, D. J., and Malin, G.: Iodomethane production by two important marine cyanobacteria: Prochlorococcus marinus (CCMP 2389) and Synechococcus sp (CCMP 2370), Mar. Chem., 125, 19-25, doi:10.1016/j.marchem.2011.01.007, 2011.

Hughes, C., Johnson, M., Utting, R., Turner, S., Malin, G., Clarke, A., and Liss, P. S.: Microbial control of bromocarbon concentrations in coastal waters of the Western Antarctic Peninsula, Mar Chem., 151, 35-46, doi:10.1016/j.marchem.2013.01.007, 2013.

Jones, C. E. and Carpenter, L. J.: Solar photolysis of $\mathrm{CH}_{2} \mathrm{I}_{2}$, $\mathrm{CH}_{2} \mathrm{ICI}$, and $\mathrm{CH}_{2} \mathrm{IBr}$ in water, saltwater, and seawater, Environ. Sci. Technol., 39, 6130-6137, doi:10.1021/es050563g, 2005.

Jones, C. E. and Carpenter, L. J.: Chemical destruction of $\mathrm{CH}_{3} \mathrm{I}$, $\mathrm{C}_{2} \mathrm{H}_{5} \mathrm{I}, 1-\mathrm{C}_{3} \mathrm{H}_{7} \mathrm{I}$, and 2- $\mathrm{C}_{3} \mathrm{H}_{7} \mathrm{I}$ in saltwater, Geophys. Res. Lett., 34, L13804, doi:10.1029/2007g1029775, 2007.

Jones, C. E., Hornsby, K. E., Sommariva, R., Dunk, R. M., Von Glasow, R., McFiggans, G., and Carpenter, L. J.: Quantifying the contribution of marine organic gases to atmospheric iodine, Geophys. Res. Lett., 37, L18804, doi:10.1029/2010g1043990, 2010.

Karstensen, J., Stramma, L., and Visbeck, M.: Oxygen minimum zones in the Eastern tropical Atlantic and Pacific Oceans, Prog Oceanogr., 77, 331-350, doi:10.1016/j.pocean.2007.05.009, 2008. 
Krüger, K. and Quack, B.: Introduction to special issue: the TransBrom Sonne expedition in the tropical West Pacific, Atmos. Chem. Phys., 13, 9439-9446, doi:10.5194/acp-13-9439-2013, 2013.

Lampel, J., Frieß, U., and Platt, U.: The impact of vibrational Raman scattering of air on DOAS measurements of atmospheric trace gases, Atmos. Meas. Tech., 8, 3767-3787, doi:10.5194/amt-8-3767-2015, 2015.

Lawler, M. J., Mahajan, A. S., Saiz-Lopez, A., and Saltzman, E. S.: Observations of $\mathrm{I}_{2}$ at a remote marine site, Atmos. Chem. Phys., 14, 2669-2678, doi:10.5194/acp-14-2669-2014, 2014.

Lin, C. Y. and Manley, S. L.: Bromoform production from seawater treated with bromoperoxidase, Limnol. Oceanogr., 57, 18571866, doi:10.4319/lo.2012.57.6.1857, 2012.

Liu, Y. N., Yvon-Lewis, S. A., Thornton, D. C. O., Campbell, L., and Bianchi, T. S.: Spatial distribution of brominated very shortlived substances in the eastern pacific, J. Geophys. Res.-Oceans, 118, 2318-2328, doi:10.1002/jgrc.20183, 2013.

Liu, Y. N., Thornton, D. C. O., Bianchi, T. S., Arnold, W. A., Shields, M. R., Chen, J., and Yvon-Lewis, S. A.: Dissolved organic matter composition drives the marine production of brominated very short-lived substances, Environ. Sci. Technol., 49, 3366-3374, doi:10.1021/es505464k, 2015.

Mahajan, A. S., Plane, J. M. C., Oetjen, H., Mendes, L., Saunders, R. W., Saiz-Lopez, A., Jones, C. E., Carpenter, L. J., and McFiggans, G. B.: Measurement and modelling of tropospheric reactive halogen species over the tropical Atlantic Ocean, Atmos. Chem. Phys., 10, 4611-4624, doi:10.5194/acp-10-4611-2010, 2010.

Mahajan, A. S., Gómez Martín, J. C., Hay, T. D., Royer, S.-J., Yvon-Lewis, S., Liu, Y., Hu, L., Prados-Roman, C., Ordóñez, C., Plane, J. M. C., and Saiz-Lopez, A.: Latitudinal distribution of reactive iodine in the Eastern Pacific and its link to open ocean sources, Atmos. Chem. Phys., 12, 11609-11617, doi:10.5194/acp-12-11609-2012, 2012.

Manley, S. L. and de la Cuesta, J. L.: Methyl iodide production from marine phytoplankton cultures, Limnol. Oceanogr., 42, 142-147, doi:10.4319/lo.1997.42.1.0142, 1997.

Martino, M., Liss, P. S., and Plane, J. M. C.: Wavelengthdependence of the photolysis of diiodomethane in seawater, Geophys. Res. Lett., 33, L06606, doi:10.1029/2005g1025424, 2006.

Martino, M., Mills, G. P., Woeltjen, J., and Liss, P. S.: A new source of volatile organoiodine compounds in surface seawater, Geophys. Res. Lett., 36, L01609, doi:10.1029/2008g1036334, 2009.

Moore, R. M. and Groszko, W.: Methyl iodide distribution in the ocean and fluxes to the atmosphere, J. Geophys. Res.-Oceans, 104, 11163-11171, doi:10.1029/1998jc900073, 1999.

Moore, R. M. and Zafiriou, O. C.: Photochemical production of methyl-iodide in seawater, J. Geophys. Res.-Atmos., 99, 1641516420, doi:10.1029/94jd00786, 1994.

Moore, R. M., Geen, C. E., and Tait, V. K.: Determination of henry law constants for a suite of naturally-occurring halogenated methanes in seawater, Chemosphere, 30, 1183-1191, doi:10.1016/0045-6535(95)00009-w, 1995.

Moore, R. M., Webb, M., Tokarczyk, R., and Wever, R.: Bromoperoxidase and iodoperoxidase enzymes and production of halogenated methanes in marine diatom cultures, J. Geophys. Res.Oceans, 101, 20899-20908, doi:10.1029/96jc01248, 1996.

Nightingale, P. D., Malin, G., Law, C. S., Watson, A. J., Liss, P. S., Liddicoat, M. I., Boutin, J., and Upstill-Goddard, R. C.: In situ evaluation of air-sea gas exchange parameterizations using novel conservative and volatile tracers, Global Biogeochem. Cy., 14, 373-387, doi:10.1029/1999gb900091, 2000.

O’Dowd, C. D., Jimenez, J. L., Bahreini, R., Flagan, R. C., Seinfeld, J. H., Hameri, K., Pirjola, L., Kulmala, M., Jennings, S. G., and Hoffmann, T.: Marine aerosol formation from biogenic iodine emissions, Nature, 417, 632-636, doi:10.1038/nature00775, 2002.

Peters, C., Pechtl, S., Stutz, J., Hebestreit, K., Hönninger, G., Heumann, K. G., Schwarz, A., Winterlik, J., and Platt, U.: Reactive and organic halogen species in three different European coastal environments, Atmos. Chem. Phys., 5, 3357-3375, doi:10.5194/acp-5-3357-2005, 2005.

Platt, U. and Stutz, J.: Differential optical absorption spectroscopy - principles and applications, Physics of earth and space environments, edited by: Guzzi, R., Lanzerotti, L. J., Imboden, D., and Platt, U., Springer Berlin Heidelberg, Berlin, Germany, 597 pp., doi:10.1007/978-3-540-75776-4, 2008.

Prados-Roman, C., Cuevas, C. A., Hay, T., Fernandez, R. P., Mahajan, A. S., Royer, S.-J., Galí, M., Simó, R., Dachs, J., Großmann, K., Kinnison, D. E., Lamarque, J.-F., and Saiz-Lopez, A.: Iodine oxide in the global marine boundary layer, Atmos. Chem. Phys., 15, 583-593, doi:10.5194/acp-15-583-2015, 2015.

Quack, B. and Wallace, D. W. R.: Air-sea flux of bromoform: Controls, rates, and implications, Global Biogeochem. Cy., 17, 1023, doi:10.1029/2002gb001890, 2003.

Quack, B., Atlas, E., Petrick, G., Stroud, V., Schauffler, S., and Wallace, D. W. R.: Oceanic bromoform sources for the tropical atmosphere, Geophys. Res. Lett., 31, L23S05, doi:10.1029/2004gl020597, 2004.

Quack, B., Atlas, E., Petrick, G., and Wallace, D. W. R.: Bromoform and dibromomethane above the Mauritanian upwelling: Atmospheric distributions and oceanic emissions, J. Geophys. Res.Atmos., 112, D09312, doi:10.1029/2006jd007614, 2007a.

Quack, B., Peeken, I., Petrick, G., and Nachtigall, K.: Oceanic distribution and sources of bromoform and dibromomethane in the Mauritanian upwelling, J. Geophys. Res.-Oceans, 112, C10006, doi:10.1029/2006jc003803, 2007b

Raimund, S., Quack, B., Bozec, Y., Vernet, M., Rossi, V., Garçon, V., Morel, Y., and Morin, P.: Sources of short-lived bromocarbons in the Iberian upwelling system, Biogeosciences, 8, 15511564, doi:10.5194/bg-8-1551-2011, 2011.

Read, K. A., Mahajan, A. S., Carpenter, L. J., Evans, M. J., Faria, B. V. E., Heard, D. E., Hopkins, J. R., Lee, J. D., Moller, S. J., Lewis, A. C., Mendes, L., McQuaid, J. B., Oetjen, H., Saiz-Lopez, A., Pilling, M. J., and Plane, J. M. C.: Extensive halogen-mediated ozone destruction over the tropical Atlantic Ocean, Nature, 453, 1232-1235, doi:10.1038/nature07035, 2008.

Richter, U. and Wallace, D. W. R.: Production of methyl iodide in the tropical Atlantic Ocean, Geophys. Res. Lett., 31, L23S03, doi:10.1029/2004g1020779, 2004.

Saiz-Lopez, A., Lamarque, J.-F., Kinnison, D. E., Tilmes, S., Ordóñez, C., Orlando, J. J., Conley, A. J., Plane, J. M. C., Mahajan, A. S., Sousa Santos, G., Atlas, E. L., Blake, D. R., Sander, S. P., Schauffler, S., Thompson, A. M., and Brasseur, G.: Estimating the climate significance of halogen-driven ozone loss in the tropical marine troposphere, Atmos. Chem. Phys., 12, 3939-3949, doi:10.5194/acp-12-3939-2012, 2012a. 
Saiz-Lopez, A., Plane, J. M. C., Baker, A. R., Carpenter, L. J., von Glasow, R., Martin, J. C. G., McFiggans, G., and Saunders, R. W.: Atmospheric chemistry of iodine, Chem. Rev., 112, 17731804, doi:10.1021/cr200029u, 2012b.

Saiz-Lopez, A., Baidar, S., Cuevas, C. A., Koenig, T. K., Fernandez, R. P., Dix, B., Kinnison, D. E., Lamarque, J.-F., RodriguezLLoveras, X., Campos, T. L., and Volkamer, R.: Injection of iodine to the stratosphere, Geophys. Res. Lett., 42, 6852-6859, doi:10.1002/2015GL064796, 2015.

Salawitch, R. J.: Atmospheric chemistry - biogenic bromine, Nature, 439, 275-277, doi:10.1038/439275a, 2006.

Scarratt, M. G. and Moore, R. M.: Production of methyl bromide and methyl chloride in laboratory cultures of marine phytoplankton ii, Mar. Chem., 59, 311-320, doi:10.1016/s03044203(97)00092-3, 1998.

Schauffler, S. M., Atlas, E. L., Flocke, F., Lueb, R. A., Stroud, V., and Travnicek, W.: Measurements of bromine containing organic compounds at the tropical tropopause, Geophys. Res. Lett., 25, 317-320, doi:10.1029/98GL00040, 1998.

Schönhardt, A., Richter, A., Wittrock, F., Kirk, H., Oetjen, H., Roscoe, H. K., and Burrows, J. P.: Observations of iodine monoxide columns from satellite, Atmos. Chem. Phys., 8, 637-653, doi:10.5194/acp-8-637-2008, 2008.

Sherwen, T., Schmidt, J. A., Evans, M. J., Carpenter, L. J., Großmann, K., Eastham, S. D., Jacob, D. J., Dix, B., Koenig, T. K., Sinreich, R., Ortega, I., Volkamer, R., Saiz-Lopez, A., PradosRoman, C., Mahajan, A. S., and Ordóñez, C.: Global impacts of tropospheric halogens $(\mathrm{Cl}, \mathrm{Br}, \mathrm{I})$ on oxidants and composition in GEOS-Chem, Atmos. Chem. Phys. Discuss., doi:10.5194/acp2016-424, in review, 2016.

Shi, Q., Marandino, C., Petrick, G., Quack, B., and Wallace, D.: A time series of incubation experiments to examine the production and loss of $\mathrm{CH}_{3} \mathrm{I}$ in surface seawater, J. Geophys. Res.-Oceans, 119, 8242-8254, doi:10.1002/2014jc010223, 2014.

Smythe-Wright, D., Boswell, S. M., Breithaupt, P., Davidson, R. D., Dimmer, C. H., and Diaz, L. B. E.: Methyl iodide production in the ocean: Implications for climate change, Global Biogeochem. Cy., 20, GB3003, doi:10.1029/2005gb002642, 2006.

Sommariva, R. and von Glasow, R.: Multiphase halogen chemistry in the tropical Atlantic Ocean, Environ. Sci. Technol., 46, 1042910437, doi:10.1021/es300209f, 2012.

Stemmler, I., Hense, I., Quack, B., and Maier-Reimer, E.: Methyl iodide production in the open ocean, Biogeosciences, 11, 44594476, doi:10.5194/bg-11-4459-2014, 2014.

Stohl, A. and Trickl, T.: A textbook example of long-range transport: Simultaneous observation of ozone maxima of stratospheric and North American origin in the free troposphere over Europe, J. Geophys. Res.-Atmos., 104, 30445-30462, doi:10.1029/1999jd900803, 1999.

Stohl, A., Forster, C., Frank, A., Seibert, P., and Wotawa, G.: Technical note: The Lagrangian particle dispersion model FLEXPART version 6.2, Atmos. Chem. Phys., 5, 2461-2474, doi:10.5194/acp-5-2461-2005, 2005.

Tanhua, T., Fogelqvist, E., and Basturk, O.: Reduction of volatile halocarbons in anoxic seawater, results from a study in the Black Sea, Mar. Chem., 54, 159-170, doi:10.1016/03044203(96)00005-9, 1996.

Taylor, B. B., Torrecilla, E., Bernhardt, A., Taylor, M. H., Peeken, I., Röttgers, R., Piera, J., and Bracher, A.: Bio-optical provinces in the eastern Atlantic Ocean and their biogeographical relevance, Biogeosciences, 8, 3609-3629, doi:10.5194/bg-8-36092011, 2011.

Tegtmeier, S., Krüger, K., Quack, B., Atlas, E., Blake, D. R., Boenisch, H., Engel, A., Hepach, H., Hossaini, R., Navarro, M. A., Raimund, S., Sala, S., Shi, Q., and Ziska, F.: The contribution of oceanic methyl iodide to stratospheric iodine, Atmos. Chem. Phys., 13, 11869-11886, doi:10.5194/acp-13-11869-2013, 2013.

Theiler, R., Cook, J. C., and Hager, L. P.: Halohydrocarbon synthesis by bromoperoxidase, Science, 202, 1094-1096, doi:10.1126/science.202.4372.1094, 1978.

Tokarczyk, R. and Moore, R. M.: Production of volatile organohalogens by phytoplankton cultures, Geophys. Res. Lett., 21, 285288, doi:10.1029/94GL00009, 1994.

Tomczak, M. and Godfrey, J. S.: Regional oceanography: An introduction, 2 ed., Daya Publishing House, Delhi, India, 2005.

Uitz, J., Claustre, H., Morel, A., and Hooker, S. B.: Vertical distribution of phytoplankton communities in open ocean: An assessment based on surface chlorophyll, J. Geophys. Res.-Oceans, 111, C08005, doi:10.1029/2005jc003207, 2006.

Varner, R. K., Zhou, Y., Russo, R. S., Wingenter, O. W., Atlas, E., Stroud, C., Mao, H., Talbot, R., and Sive, B. C.: Controls on atmospheric chloroiodomethane $\left(\mathrm{CH}_{2} \mathrm{ClI}\right)$ in marine environments, J. Geophys. Res.-Atmos., 113, D10303, doi:10.1029/2007jd008889, 2008.

Vidussi, F., Claustre, H., Manca, B. B., Luchetta, A., and Marty, J. C.: Phytoplankton pigment distribution in relation to upper thermocline circulation in the eastern mediterranean sea during winter, J. Geophys. Res.-Oceans, 106, 19939-19956, doi:10.1029/1999jc000308, 2001.

Volkamer, R., Coburn, S. C., Dix, B. K., and Sinreich, R.: The eastern pacific ocean is a source for short lived atmospheric gases: Glyoxal and iodine oxide, CLIVAR, Newsletter of the Climate Variability and Predictability Programme (CLIVAR), 15, 30-33, 2010.

von Glasow, R., von Kuhlmann, R., Lawrence, M. G., Platt, U., and Crutzen, P. J.: Impact of reactive bromine chemistry in the troposphere, Atmos. Chem. Phys., 4, 2481-2497, doi:10.5194/acp-42481-2004, 2004.

Wang, S. Y., Schmidt, J. A., Baidar, S., Coburn, S., Dix, B., Koenig, T. K., Apel, E., Bowdalo, D., Campos, T. L., Eloranta, E., Evans, M. J., DiGangi, J. P., Zondlo, M. A., Gao, R. S., Haggerty, J. A., Hall, S. R., Hornbrook, R. S., Jacob, D., Morley, B., Pierce, B., Reeves, M., Romashkin, P., ter Schure, A., and Volkamer, R.: Active and widespread halogen chemistry in the tropical and subtropical free troposphere, P. Natl. Acad. Sci. USA, 112, 92819286, doi:10.1073/pnas.1505142112, 2015.

White, R. H.: Analysis of dimethyl sulfonium compounds in marine-algae, J. Mar. Res., 40, 529-536, 1982.

Wurl, O., Wurl, E., Miller, L., Johnson, K., and Vagle, S.: Formation and global distribution of sea-surface microlayers, Biogeosciences, 8, 121-135, doi:10.5194/bg-8-121-2011, 2011.

Yamamoto, H., Yokouchi, Y., Otsuki, A., and Itoh, H.: Depth profiles of volatile halogenated hydrocarbons in seawater in the Bay of Bengal, Chemosphere, 45, 371-377, doi:10.1016/s00456535(00)00541-5, 2001.

Yilmaz, S.: Retrieval of atmospheric aerosol and trace gas vertical profiles using multi-axis differential optical absorption spec- 
troscopy, Institut für Umweltphysik, Universität Heidelberg, Heidelberg, Germany, 2012.

Yokouchi, Y., Saito, T., Ooki, A., and Mukai, H.: Diurnal and seasonal variations of iodocarbons $\left(\mathrm{CH}_{2} \mathrm{ClI}, \mathrm{CH}_{2} \mathrm{I}_{2}, \mathrm{CH}_{3} \mathrm{I}\right.$, and $\mathrm{C}_{2} \mathrm{H}_{5} \mathrm{I}$ ) in the marine atmosphere, J. Geophys. Res.-Atmos., 116, D06301, doi:10.1029/2010jd015252, 2011.

Yokouchi, Y., Ooki, A., Hashimoto, S., and Itoh, H.: A study on the production and emission of marine-derived volatile halocarbons, in: Western Pacific air-sea interactions study, edited by: Uematsu, M., Yokouchi, Y., Watanabe, Y. W., Takeda, S., and Yamanaka, Y., TERRAPUB, Okusawa, 1-25, 2014.

Zafiriou, O. C.: Reaction of methyl halides with seawater and marine aerosols, J. Mar. Res., 33, 75-81, 1975.
Ziska, F., Quack, B., Abrahamsson, K., Archer, S. D., Atlas, E., Bell, T., Butler, J. H., Carpenter, L. J., Jones, C. E., Harris, N. R. P., Hepach, H., Heumann, K. G., Hughes, C., Kuss, J., Krüger, K., Liss, P., Moore, R. M., Orlikowska, A., Raimund, S., Reeves, C. E., Reifenhäuser, W., Robinson, A. D., Schall, C., Tanhua, T., Tegtmeier, S., Turner, S., Wang, L., Wallace, D., Williams, J., Yamamoto, H., Yvon-Lewis, S., and Yokouchi, Y.: Global sea-toair flux climatology for bromoform, dibromomethane and methyl iodide, Atmos. Chem. Phys., 13, 8915-8934, doi:10.5194/acp13-8915-2013, 2013. 